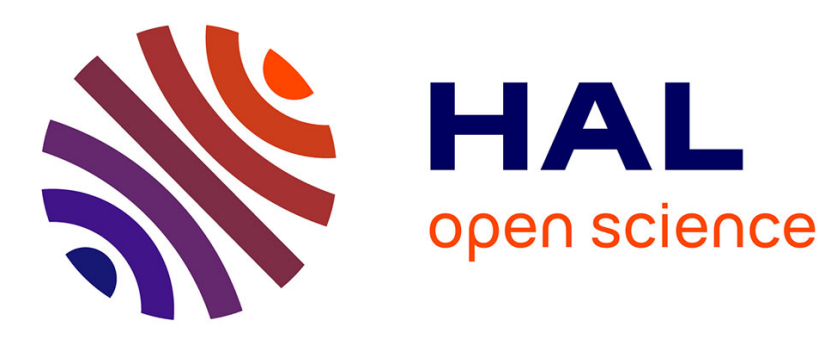

\title{
Dislocation creep of dry quartz
}

\author{
Rüdiger K Kilian, Renée Heilbronner, Caleb W Holyoke Iii, Andreas K \\ Kronenberg, Holger Stünitz
}

\section{To cite this version:}

Rüdiger K Kilian, Renée Heilbronner, Caleb W Holyoke Iii, Andreas K Kronenberg, Holger Stünitz. Dislocation creep of dry quartz. Journal of Geophysical Research: Solid Earth, 2016, 121, pp.3278 3299. 10.1002/2015JB012771 . insu-01376759

\section{HAL Id: insu-01376759 https://hal-insu.archives-ouvertes.fr/insu-01376759}

Submitted on 5 Oct 2016

HAL is a multi-disciplinary open access archive for the deposit and dissemination of scientific research documents, whether they are published or not. The documents may come from teaching and research institutions in France or abroad, or from public or private research centers.
L'archive ouverte pluridisciplinaire HAL, est destinée au dépôt et à la diffusion de documents scientifiques de niveau recherche, publiés ou non, émanant des établissements d'enseignement et de recherche français ou étrangers, des laboratoires publics ou privés. 


\section{Journal of Geophysical Research: Solid Earth}

\author{
RESEARCH ARTICLE \\ 10.1002/2015JB012771 \\ Key Points: \\ - Very low water concentrations in \\ naturally deformed quartz \\ - Dislocation creep at low differential \\ stress \\ - Discrepancy between natural and \\ experimental deformation
}

Correspondence to:

R. Kilian,

ruediger.kilian@unibas.ch

\section{Citation:}

Kilian, R., R. Heilbronner, C. W. Holyoke III, A. K. Kronenberg, and H. Stünitz (2016), Dislocation creep of dry quartz, J. Geophys. Res. Solid Earth, 121, 3278-3299, doi:10.1002/2015JB012771.

Received 23 DEC 2015 Accepted 11 APR 2016 Accepted article online 24 APR 2016 Published online 12 MAY 2016

\section{Dislocation creep of dry quartz}

\author{
Rüdiger Kilian ${ }^{1}$, Renée Heilbronner ${ }^{1}$, Caleb W. Holyoke $\mathrm{III}^{2}$, Andreas K. Kronenberg ${ }^{3}$, \\ and Holger Stünitz ${ }^{4,5}$
}

\begin{abstract}
${ }^{1}$ Department of Environmental Sciences, University Basel, Basel, Switzerland, ${ }^{2}$ Department of Geosciences, University of Akron, Akron, Ohio, USA, ${ }^{3}$ Department of Geology and Geophysics, Texas A\&M University, College Station, Texas, USA, ${ }^{4}$ Department of Geology, University of Tromso, Tromso, Norway, ${ }^{5}$ Institut des Sciences de la Terre, Université d'Orléans, Orleans CEDEX 2, France
\end{abstract}

Abstract Small-scale shear zones within the Permian Truzzo meta-granite developed during the Alpine orogeny at amphibolite facies conditions. In these shear zones magmatic quartz deformed by dislocation creep and recrystallized dynamically by grain boundary migration with minor subgrain rotation recrystallization to a grain size of around 250-750 $\mu \mathrm{m}$, consistent with flow at low differential stresses. Fourier transform infrared (FTIR) spectroscopy reveals very low water contents in the interior of recrystallized grains (in the form of discrete $\mathrm{OH}$ peaks, $\sim 20 \mathrm{H} / 10^{6} \mathrm{Si}$ and very little broad band absorption, $<100 \mathrm{H} / 10^{6} \mathrm{Si}$ ). The spectral characteristics are comparable to those of dry Brazil quartz. In FTIR spectra, magmatic quartz grains show a broad absorption band related with high water concentrations only in those areas where fluid inclusions are present while other areas are dry. Drainage of fluid inclusions and synkinematic growth of hydrous minerals indicates that a hydrous fluid has been available during deformation. Loss of intragranular water during grain boundary migration recrystallization did not result in a microstructure indicative of hardening. These FTIR measurements provide the first evidence that quartz with extremely low intragranular water contents can deform in nature by dislocation creep at low differential stresses. Low intragranular water contents in naturally deformed quartz may not be necessarily indicative of a high strength, and the results are contrary to implications taken from deformation experiments where very high water contents are required to allow dislocation creep in quartz. It is suggested that dislocation creep of quartz in the Truzzo meta-granite is possible to occur at low differential stresses because sufficient amounts of intergranular water ensure a high recovery rate by grain boundary migration while the absence of significant amounts of intragranular water is not crucial at natural conditions.

\section{Introduction}

The experimental deformation of quartz by mechanisms of dislocation glide and dislocation creep is enabled by the presence of water [e.g., Griggs and Blacic, 1964, 1965; Griggs, 1967; McLaren et al., 1983, 1989; Jaoul et al., 1984; Post and Tullis, 1998; Stipp et al., 2006], while dry quartz behaves as one of the strongest silicate minerals, deforming by brittle mechanisms at high stresses and only very limited crystal plasticity. Microstructural evidence of dislocation creep in naturally deformed quartz is widespread in greenschist facies and higher grade shear zones [e.g., Weathers et al., 1979; Law, 1986; Stipp et al., 2002], and it is commonly assumed that water plays an important role in deformation at middle to lower levels of the continental crust.

Infrared (IR) spectroscopy has been important in studies of experimentally deformed quartz samples, allowing qualitative identification of hydrogen defects and water inclusions (speciation) and quantitative analyses (of content) that can be linked to measured mechanical properties [e.g., Kronenberg, 1994]. Quartz single crystals and quartzites deform in the laboratory by dislocation mechanisms when intragranular and intergranular water is present in large quantities $\left(\gg 1000 \mathrm{H} / 10^{6} \mathrm{Si}\right.$ ). Water content can be determined by IR spectroscopy of OH bands [e.g., Kekulawala et al., 1978; Post and Tullis, 1998; Chernak et al., 2009], by weight loss measurements of native intragranular water contents [Jaoul et al., 1984; Mainprice and Jaoul, 2009], by adding known amounts of water (usually more than $10,000 \mathrm{H} / 10^{6} \mathrm{Si}$, or $\sim 0.15 \mathrm{wt} \% \mathrm{H}_{2} \mathrm{O}$ [e.g., Kronenberg and Tullis, 1984; Hirth and Tullis, 1992; Post and Tullis, 1998; Chernak et al., 2009]), or by using a combination of methods to manipulate and measure water contents (Fourier transform infrared (FTIR) and Karl-Fischer titration [Stipp et al., 2006]) (see Table 1).

In the absence of intragranular water, Brazilian and dry synthetic quartz single crystals (containing $<100 \mathrm{H} / 10^{6} \mathrm{Si}$ ) have not been deformed in the laboratory by crystal plastic mechanisms. Vacuum-dried 
Table 1. Selected Water Contents From the Literature of Naturally and Experimentally Deformed and Undeformed Quartz (Rocks) ${ }^{\mathrm{a}, \mathrm{b}}$

\begin{tabular}{|c|c|c|c|c|c|}
\hline Material & Author & $\begin{array}{c}\text { Type of } \\
\text { Measurement }\end{array}$ & $\begin{array}{l}\mathrm{H} / 10^{6} \mathrm{Si} \\
\text { (Original) }\end{array}$ & Cal. & $\begin{array}{l}\mathrm{H} / 10^{6} \text { Si, recalc. } \\
{[\text { Paterson, 1982] }}\end{array}$ \\
\hline \multicolumn{6}{|l|}{ Natural (deformed) } \\
\hline Felsic migmatite, leucosome rich $(\mathrm{d}<1 \mathrm{~mm})$ & Menegon et al. [2011] & intragranular & $5-1100$ & Ка & $10-2200$ \\
\hline Felsic migmatite, leucosome poor ( $d 80-500 \mu \mathrm{m})$ & Menegon et al. [2011] & intragranular & $10-300$ & Ка & $20-600$ \\
\hline Granulite facies chert $(\mathrm{d}<8 \mathrm{~mm})$ & Nakashima et al. [1995] & intragranular & 270 & $\mathrm{Ag}$ & 560 \\
\hline Ryoke granitoid mylonites (low-high stain) & Nakashima et al. [1995] & bulk & $2000-16,675$ & $\mathrm{Ag}$ & $4000-32,000$ \\
\hline Sambagawa metasediments (chlorite zone) & Nakashima et al. [1995] & bulk & 6670 & $\mathrm{Ag}$ & 12,000 \\
\hline Sambagawa metasediments (olig- bt zone) & Nakashima et al. [1995] & bulk & 1330 & $\mathrm{Ag}$ & 2600 \\
\hline Pegmatite & Kronenberg et al. [1990] & Bulk $\left({ }^{d}\right)$ & 120 & Ka & 240 \\
\hline Pegmatite ( $d=3 \mathrm{~cm} !)$ & Gleason and DeSisto [2008] & intragranular & $20-40$ & $\mathrm{Ka}$ & $40-80$ \\
\hline Granodiorite & Kronenberg et al. [1990] & bulk & 1050 & Ка & 2100 \\
\hline Gneiss $(d=0.5-3 \mathrm{~mm})$ & Gleason and DeSisto [2008] & intragranular & $20-820$ & $\mathrm{Ka}$ & $40-1600$ \\
\hline Mylonitic granodiorite & Kronenberg et al. [1990] & bulk & 8800 & Ка & 17600 \\
\hline Mylonite $(120-160 \mu \mathrm{m})$ & Gleason and DeSisto [2008] & intragranular-bulk & $50-1120$ & Ка & $100-2200$ \\
\hline Barre granite & Kronenberg and Wolf [1990] & intragranular + FI & 500 & Ka & 945 \\
\hline Quartzite Moine thrust & Kronenberg and Wolf [1990] & bulk & $1400-7500$ & Ка & $2645-14,100$ \\
\hline \multicolumn{6}{|l|}{ Experimental (deformed) } \\
\hline Heavitree (undeformed) as-is & Mainprice and Jaoul [2009] & bulk & 2759 & Pat & 2759 \\
\hline Heavitree (undeformed) as-is & Kronenberg and Wolf [1990] & bulk & 3900 & Ка & 7300 \\
\hline Heavitree (undeformed) as-is & Post and Tullis [1998] & intragranular & $1750 \pm 420$ & $\mathrm{Ka}$ & $3300 \pm 790$ \\
\hline \multirow[t]{2}{*}{ Heavitree (undeformed) vacuum-dried } & Post and Tullis [1998] & intragranular & mean $240 \pm 60$ & $\mathrm{Ka}$ & $450 \pm 120$ \\
\hline & & & $70-660$ & & $130-1250$ \\
\hline Heavitree deformed, $700^{\circ} \mathrm{C}, 0.58 \mathrm{wt} \% \mathrm{H}_{2} \mathrm{O}$ added & Kronenberg and Wolf [1990] & bulk & 3800 & Ка & 7200 \\
\hline Heavitree deformed, $800^{\circ} \mathrm{C}, 0.54 \mathrm{wt} \% \mathrm{H}_{2} \mathrm{O}$ added & Kronenberg and Wolf [1990] & bulk & 4100 & Ка & 7800 \\
\hline \multirow{2}{*}{ Heavitree hydrost. annealed, $800^{\circ} \mathrm{C}, 0.3 \mathrm{wt} \% \mathrm{H}_{2} \mathrm{O}$ added } & Post and Tullis [1998] & intragranular & mean $730 \pm 150$ & Ка & $1390 \pm 150$ \\
\hline & & & $350-1280$ & & $660-2400$ \\
\hline \multirow{2}{*}{ Heavitree, deformed, $800^{\circ} \mathrm{C}, 0.3 \mathrm{wt} \% \mathrm{H}_{2} \mathrm{O}$ added } & Post and Tullis [1998] & intragranular & mean $820 \pm 160$ & Ka & $1550 \pm 300$ \\
\hline & & & $140-2360$ & & $260-4480$ \\
\hline Dongelberg deformed, $800^{\circ} \mathrm{C}, \sim 0.4 \mathrm{wt} \% \mathrm{H}_{2} \mathrm{O}$ added & den Brok et al. [1994] & intragranular & $<200-2900$ & Pat & $<200-2900$ \\
\hline $\mathrm{BHQ}$ (undeformed) as-is & Chernak et al. [2009] & bulk & 5800 & St & 4900 \\
\hline $\mathrm{BHQ}$ deformed, $900^{\circ} \mathrm{C}$ "as is" & Chernak et al. [2009] & bulk & 2300 & St & 1900 \\
\hline $\mathrm{BHQ}$ deformed, $900^{\circ} \mathrm{C}, 0.5 \mathrm{wt} \% \mathrm{H}_{2} \mathrm{O}$ added & Chernak et al. [2009] & bulk & 4000 & St & 3400 \\
\hline $\mathrm{BHQ}$ (undeformed) as-is & Stipp et al. [2006] & bulk & 4270 & $\mathrm{St} / \mathrm{Pat}{ }^{\mathrm{C}}$ & $3500 / 2600^{c}$ \\
\hline BHQ deformed, $1000-1100^{\circ} \mathrm{C}$,vacuum-dried & Stipp et al. [2006] & bulk & 1735 & $\mathrm{St} / \mathrm{Pat}{ }^{\mathrm{C}}$ & $1470 / 1200^{C}$ \\
\hline $\mathrm{BHQ}$ deformed, $900-1100^{\circ} \mathrm{C}$, as-is & Stipp et al. [2006] & bulk & 2270 & $\mathrm{St} / \mathrm{Pat}{ }^{\mathrm{C}}$ & $1870 / 1600^{C}$ \\
\hline BHQ deformed, $750-950^{\circ} \mathrm{C}, 0.2$ wt $\% \mathrm{H}_{2} \mathrm{O}$ added $^{\mathrm{e}}$ & Stipp et al. [2006] & bulk & 2860 & $\mathrm{St} / \mathrm{Pat}{ }^{\mathrm{c}}$ & $2344 / 2070^{c}$ \\
\hline \multicolumn{6}{|l|}{ Synthetic/natural standards } \\
\hline Brazilian quartz (crystal A-1) & Kronenberg and Wolf [1990] & intragranular & $25-90$ & Ка & $50-160$ \\
\hline Brazilian quartz (crystal A-1) & Blacic [1975] & intragranular & 10 & $\mathrm{Br}$ & 15 \\
\hline X-13 (synthetic) & [Kronenberg and Wolf [1990] & intragranular & 1600 & Ка & 3020 \\
\hline X-13 (synthetic) & Blacic $[1975]$ & intragranular & 2575 & $\mathrm{Br}$ & 3800 \\
\hline X0 (synthetic) & Kronenberg and Wolf [1990] & intragranular & 3223 & Ка & 6080 \\
\hline X0 (synthetic) & Blacic [1975] & intragranular & 4350 & $\mathrm{Br}$ & 6400 \\
\hline
\end{tabular}

\footnotetext{
${ }^{\mathrm{a}}$ Heavitree, BHQ (Black Hills quartzite), and Dongelberg are quartzites.
${ }^{\mathrm{b}}$ Abbreviations used for calibrations: $\mathrm{Ka}=$ Kats,1962, Pat $=$ Paterson [1982] $<\mathrm{St}=$ Stipp et al. [2006], Br $=$ Brunner et al. [1961] corrected after Pat, Ag= Agate calibration for pure $\mathrm{H}_{2} \mathrm{O}$.

${ }^{c}$ No conversion factor was used because their spectra have a nonstandard shape.

${ }^{d}$ Measurement reflects rather intragranular content due to very large grain size.

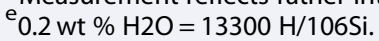

natural quartzites have water concentrations of several hundreds of $\mathrm{H} / 10^{6} \mathrm{Si}$ [Post and Tullis, 1998; Stipp et al., 2006], and experimental deformation by dislocation processes is limited, often accompanied by abundant fracturing [Mainprice and Jaoul, 2009].

With the advent of Fourier infrared spectroscopy (FTIR) and IR microscopes, spectroscopic studies of water species are also possible in smaller sampling volumes necessary to characterize $\mathrm{OH}$ and water defects in individual, sufficiently large grains of naturally deformed rocks. Water and water-related defects can be incorporated in a number of forms, as freezable fluid inclusions, as nonfreezable molecular $\mathrm{H}_{2} \mathrm{O}$ (fine clusters and adsorbed surface species that interact with neighboring quartz bonds), and $\mathrm{H} / \mathrm{OH}$ bound to the crystal lattice in various structural and defect sites. 

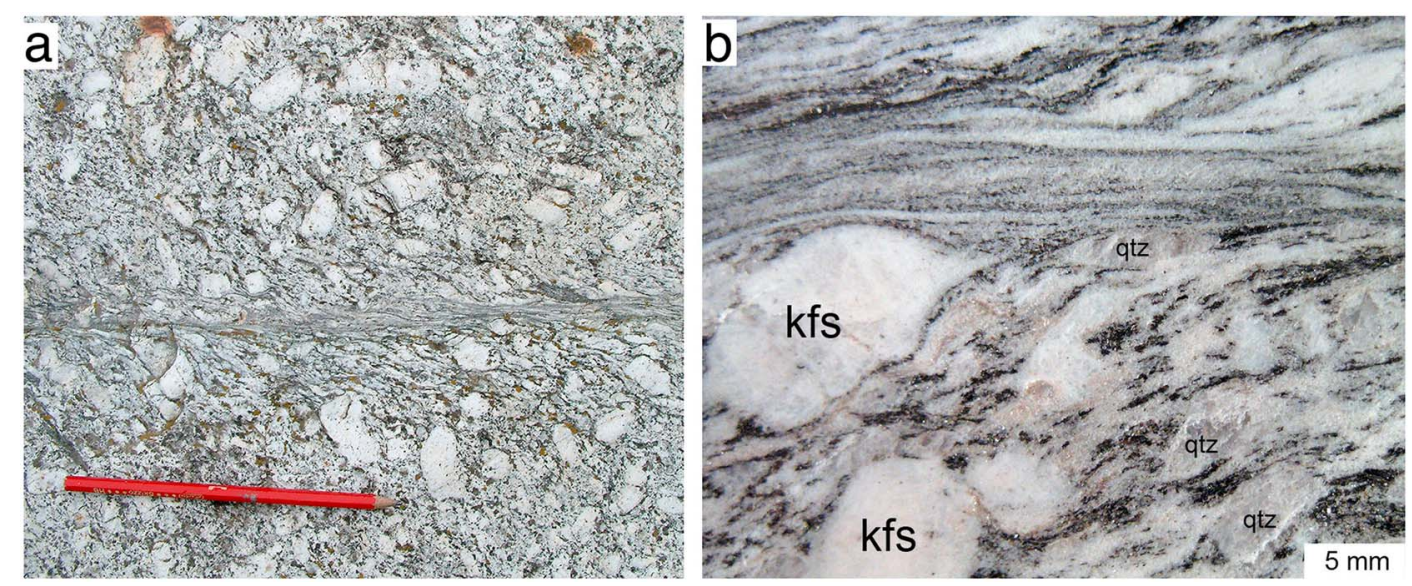

Figure 1. Shear zones in the Truzzo meta-granite: (a) outcrop photographs of a typical small scale shear zone in the undeformed Truzzo meta-granite and (b) a polished hand specimen of a small-scale shear zone in a weakly deformed Truzzo meta-granite. Toward the shear zone center, K-feldspar grains (kfs) form tails and quartz aggregates (qtz) show increasing aspect ratios.

Bulk water concentrations measured in natural quartz mylonites deformed by dislocation creep range from $\sim 100$ and to $>10,000 \mathrm{H} / 10^{6} \mathrm{Si}$ [e.g., Kronenberg and Wolf, 1990; Kronenberg et al., 1990; Nakashima et al., 1995; Gleason and DeSisto, 2008]. The dependence of quartz strength on water for naturally deformed rocks cannot be determined directly, but it has been inferred on the basis of measured strains, deformation microstructures, and FTIR spectroscopy on polycrystalline aggregates [Kronenberg et al., 1990]. The bulk water concentrations found in greenschist facies mylonites are comparable to the amounts of water required for dislocation creep in experimental deformation.

In some high-temperature mylonites deforming by dislocation creep, deformation microstructures, such as a small recrystallized quartz grain size, occasionally synkinematically developed pseudotachylites, indicate that differential stresses were large and may be interpreted to relate to water-deficient conditions [Passchier, 1985; Pennacchioni and Cesare, 1997; Mancktelow and Pennacchioni, 2004; Fitz Gerald et al., 2006; Menegon et al., 2011].

However, evidence of water weakening depends on a number of assumptions, which have not been tested. First, dynamic recrystallization in deformation experiments and in rocks deformed at high stresses in nature, results in grain sizes for which FTIR spectra cannot be collected from individual grains. Absorption bands include $\mathrm{OH}$ stretching vibrations from $\mathrm{H} / \mathrm{OH}$ defects, fluid inclusions, and adsorbed $\mathrm{H} / \mathrm{OH}$ species and water at grain boundaries. Thus, increased water contents in finely recrystallized mylonites might simply reflect the presence of water along grain boundaries [lto and Nakashima, 2002] and do not necessarily indicate a higher content of water inside the deformed quartz grains. Second, the $\mathrm{H} / \mathrm{OH}$ species that have been identified by FTIR and measured water contents have been assumed to be synkinematic, unchanged during uplift and exposure of deep seated shear zones since deformation.

In this study we present microstructural evidence of dislocation creep of quartz in the Truzzo meta-granite mylonite (TGM) that deformed under amphibolite facies conditions as well as IR determinations of water species and contents in original magmatic and recrystallized quartz grains. Owing to large recrystallized grain sizes, it is possible to obtain FTIR spectra from areas within individual grains. Thus, $\mathrm{OH}$ absorptions due to intragranular water in the forms of aqueous fluid inclusions and water-related species inside grains can be distinguished from intergranular water at grain boundaries. When absorption peaks are due to structurally bound water-related defects, we will refer to these as intracrystalline water.

Although quartz microstructures in these rocks indicate that dislocation creep with recovery by grain boundary migration (GBM) operated at presumably low differential stresses, very little water is detected in the deformed and recrystallized quartz grains. This is surprising given the many quartz deformation experiments, which indicate that water is necessary for dislocation creep. Potential differences between high-temperature creep in nature and experiments are discussed, and the role of recrystallization mechanisms is examined. 


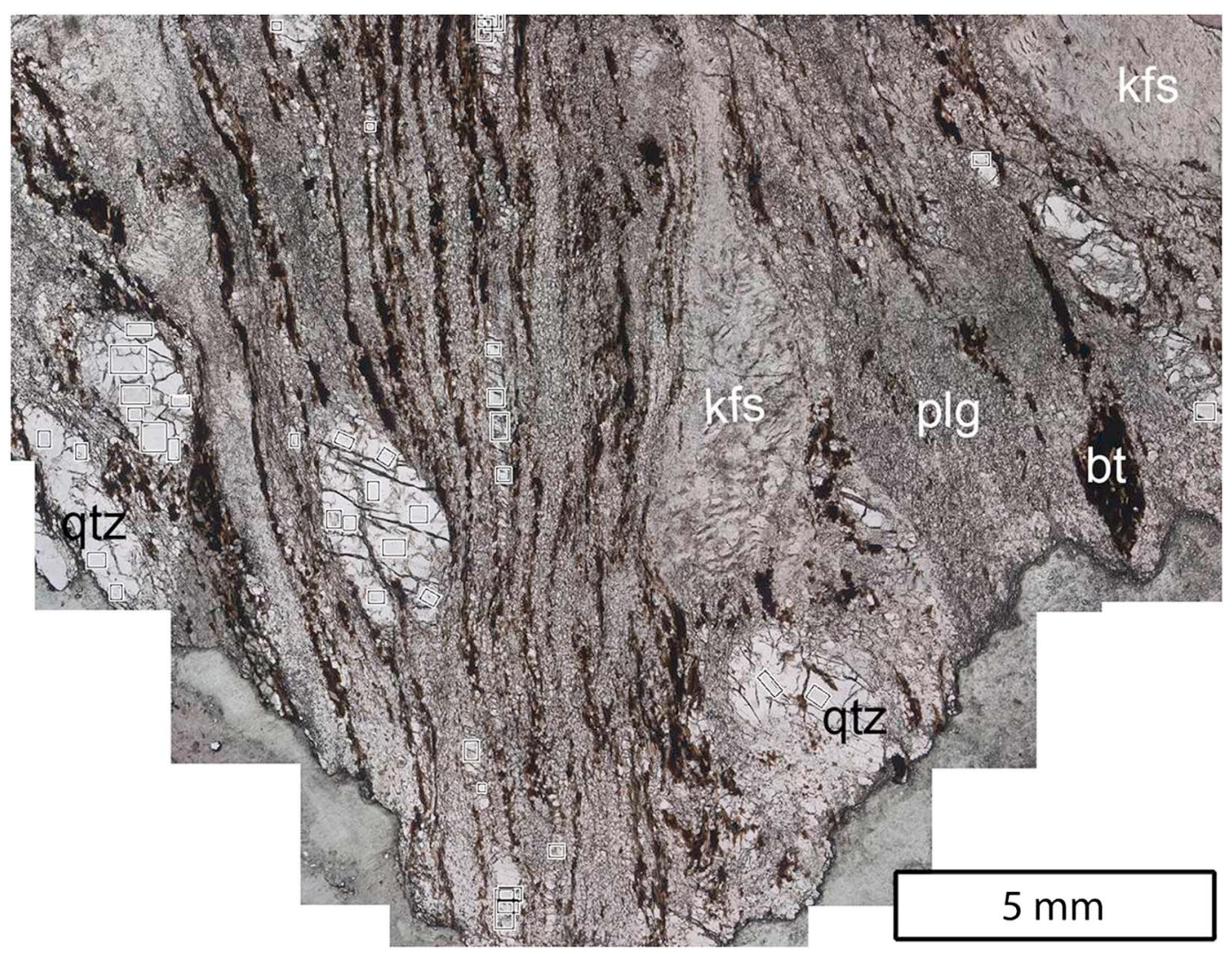

Figure 2. Samples: Mosaic of micrographs of a thick section of sample TR3. Quartz (qtz) appears clear, fine-grained plagioclase (plg) and K-feldspar (kfs) grayish and cloudy, and biotite (bt) dark brown. Small, recrystallized grains flank K-feldspar porphyroclasts (arrows). Frames roughly indicate where FTIR spectra were acquired.

\section{Methods and Material}

\subsection{Geology and Samples}

Samples were taken from small-scale (10-100 mm width) mylonitic shear zones, which formed within large (several tens of meters) low-strain domains of the Permian Truzzo meta-granite in the southernmost part of the Penninic Tambo nappe in the Central Alps (Italy, 748944,132923 to 748888,133092) (Figure 1). The Truzzo meta-granite intruded into polyphase deformed Variscan basement and its heterogeneous deformation is interpreted to be only of Alpine age [e.g., Marquer et al., 1994]. The low-strain domains of the Truzzo meta-granite still preserve magmatic structures and grade within decimeters to meters into the surrounding mylonitic orthogneiss.

A first deformation D1 produced a foliation and anastomosing shear zones on the nappe scale at pressures of up to 1.3 GPa and temperatures above $550^{\circ} \mathrm{C}$ [Marquer, 1991; Baudin and Marquer, 1993]. The second deformation D2 is thought to be associated with rapid decompression at higher temperatures around $650^{\circ} \mathrm{C}$ and 0.8-0.9 GPa in the southern Tambo nappe [Huber and Marquer, 1998] forming shear zones at all scales (related to an E-W stretching of the nappe) [Marquer, 1991; Marquer et al., 1994]. D3 deformation below $550^{\circ} \mathrm{C}$ at $0.4 \mathrm{GPa}$ is associated with a heterogeneous refolding of D1 and D2 structures; microstructures associated with this deformation have not been identified in our samples. The shear zones inside the low-strain domains investigated here are most likely related to D2 deformation but could also have been initiated during D1 deformation. Shear zones are planar over the exposed area (up to $10 \mathrm{~m}$ length). In most cases, the strain gradient at the margin of the shear zones is high. The margins of the shear zones are composed of a foliated zone of variable width, which may grade into a fine-grained ultramylonite over a distance of a few millimeter (Figure 1).

The Truzzo meta-granite host rock of the shear zones is porphyritic with several centimeter long K-feldspar phenocrysts. Samples were taken from a number of shear zones covering the entire strain gradient from undeformed at the margins to highly deformed parts in the center of the shear zones. 


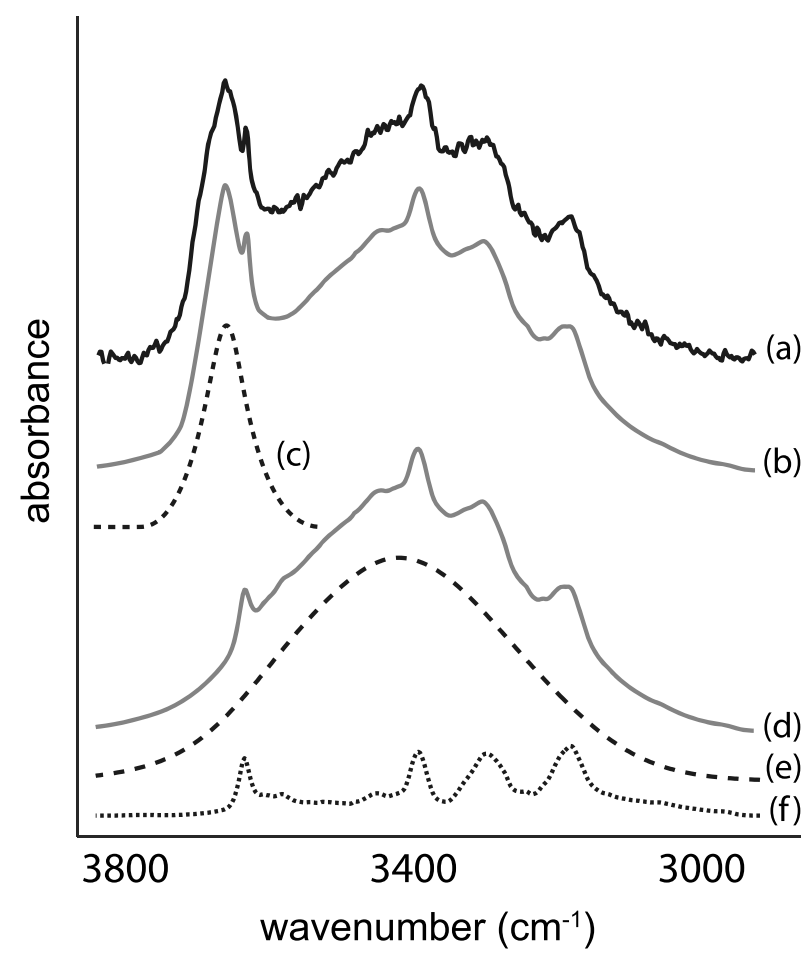

Figure 3. FTIR spectra: (a) Schematic raw FTIR spectrum composed of a broad absorption band and discrete absorption peaks. (b) An approximation is derived from the superposition of Gaussian curves. After removal of (c) a white mica related peak, (d) the total OH-related absorption spectrum in quartz is decomposed into (e) a broad absorption band related to (f) molecular water and discrete peaks related to $\mathrm{H} / \mathrm{OH}$ defects.
Samples mentioned in this study are Tr4, which contains a discrete thin shear zone (1-4 mm), formed as a C-plane in a general SC-geometry of a more highly deformed portion of Truzzo meta-granite. Sample Tr3 contains shear zones $(3-20 \mathrm{~mm})$ from a more highly deformed part of the Truzzo meta-granite, from which Section Tr3-1 contains a single, individual shear zone (Figure 2).

\subsection{Sample Preparation}

For the microstructural analysis on the light microscope and scanning electron microscope (SEM), polished thin sections of approximately $20-25 \mu \mathrm{m}$ thickness were prepared. For the FTIR analyses doublepolished thin sections of 120 to $210 \mu \mathrm{m}$ (Figure 2) were prepared using Deiberit 502 dental wax as glue. The wax shows IR peaks for the $\mathrm{CH}$ bonds at 2850, 2920, and $2955 \mathrm{~cm}^{-1}$, which can be present in spectra if the wax was not fully removed. Such spectra can be used for water quantification because the wax does not produce any significant absorption in the range of 3000$3800 \mathrm{~cm}^{-1}$. For electron backscatter diffraction (EBSD) analysis, sections were later glued on a glass slide, mechanically and chemically polished using Syton ${ }^{\circledast}$ colloidal silica.

\subsection{Microstructure and Texture}

Microstructures were examined using a polarized light and a Philips XL30 field emission SEM at the Center for Microscopy of Basel University. Orientation maps were obtained by computer-integrated polarization microscopy (CIP) [Heilbronner and Pauli, 1993; Heilbronner and Barrett, 2014] and electron backscatter diffraction (EBSD), which was carried out using the ZEISS Evo 50 SEM equipped with a Digiview II EBSD camera and OIM acquisition software at the Geological Institute of Bern University. Step sizes of EBSD maps are of 1 and $2 \mu \mathrm{m}$. The MTEX toolbox [Hielscher and Schaeben, 2008] was used for analysis of EBSD data.

Grain maps obtained from CIP-derived misorientation images were used for the analysis of surface fabrics (using the SURFOR program [Panozzo, 1983, 1984; Heilbronner and Barrett, 2014]) and grain sizes. Grain sizes (d) are obtained from the diameter of the area equivalent circle and given as the volume weighted mode of diameters of volume equivalent spheres (using STRIPSTAR [Heilbronner and Barrett, 2014]).

\subsection{Fourier Transform Infrared (FTIR) Analysis}

FTIR spectra have been acquired using a Nicolet Magna560 FTIR spectrometer with a NicPlan microscope at Texas A\&M University, Center of Tectonophysics. Spectra were recorded for wave numbers from 650 to $4000 \mathrm{~cm}^{-1}$ at a resolution of $2 \mathrm{~cm}^{-1}$ with nonpolarized light at room temperature with a collection time of $320 \mathrm{~s}$ per spectrum and 512 scans. A background was recorded for every spectrum. Variable aperture widths between $30 \times 30 \mu \mathrm{m}$ to $200 \times 200 \mu \mathrm{m}$ were used to determine spectra of individual single grains.

Various calibrations exist for the determination of the water content in quartz measured from FTIR spectra [e.g., Kats, 1962; Paterson, 1982; Libowitzky and Rossman, 1997; Stipp et al., 2006; Thomas et al., 2009]. The calibration of Kats [1962] was acquired from single crystals for discrete, sharp absorption peaks due to hydrogen interstitials bonded to structural oxygen of quartz; the calibration of Thomas et al. [2009] is similar to that of Kats [1962]. The relation of Paterson [1982] was based on calibrations for a wider range of hydrous 


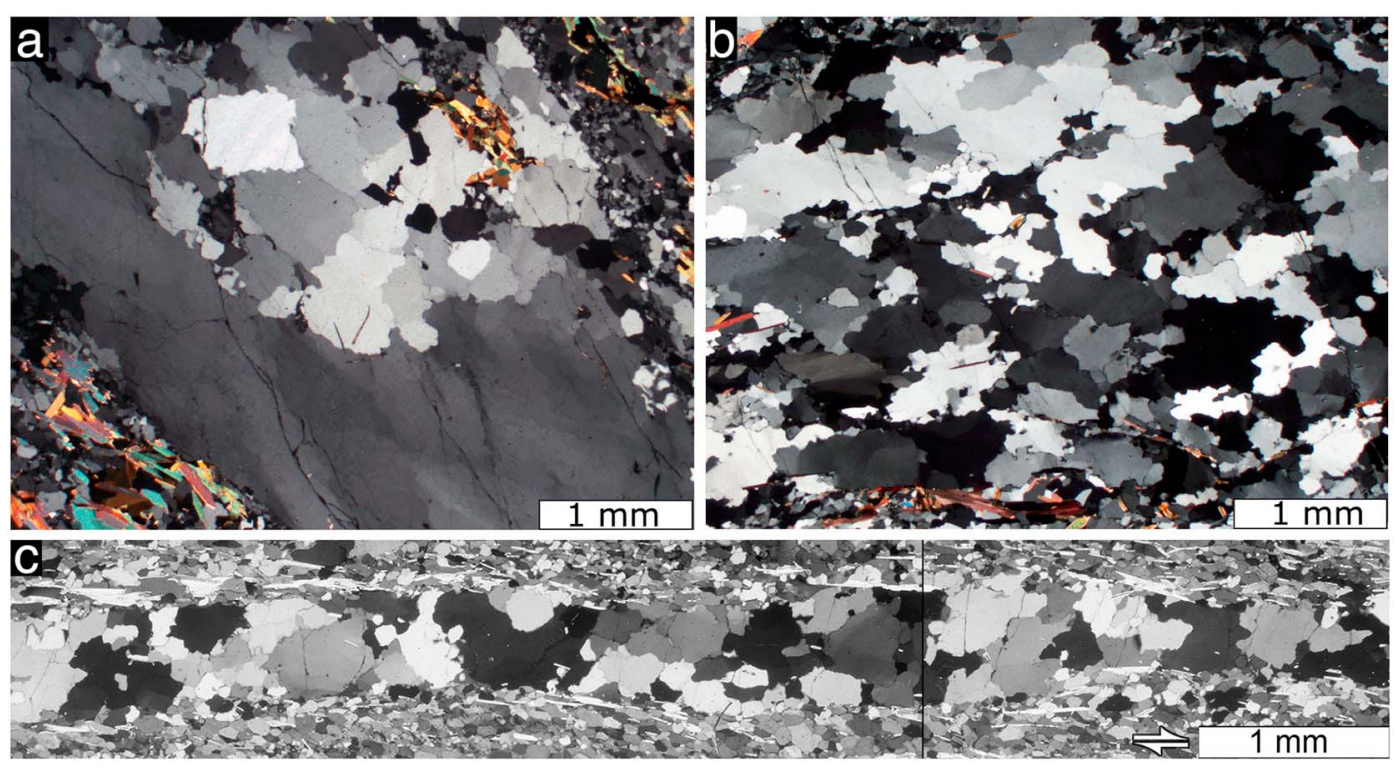

Figure 4. Progress of grain boundary migration recrystallization in quartz: (a) Magmatic quartz grain from the weakly deformed part of a shear zone, which is partially consumed by recrystallized grains. Note the lobate grain boundaries of the recrystallized grains and the subgrain boundaries in the magmatic grain. (b) Completely recrystallized quartz grain from a more highly deformed part of the shear zone. Note the slight elongation of the recrystallized grains compared to Figure 4 a. (c) Highly stretched layer of recrystallized quartz grains. Light micrographs with cross-polarized light (Figures $4 \mathrm{a}$ and $4 \mathrm{~b}$ ) and circular polarized light (Figure 4c).

complexes in silicate glasses and hydrous minerals (some with broad $\mathrm{OH}$ bands) and that of Libowitzky and Rossman [1997] was determined using hydrous minerals. The calibration of Stipp et al. [2006] was determined for polycrystalline quartz with a large contribution of the broad absorption band at $3400 \mathrm{~cm}^{-1}$ and $3600 \mathrm{~cm}^{-1}$ to the total absorbance.

For the determination of water content in the samples discussed here, the following procedure was used. Spectra were corrected for a horizontal baseline. Three curves were fitted for each absorption spectrum using superposed Gaussian curves: one for the broad absorption band centered around $3400 \mathrm{~cm}^{-1}$, one for the $\mathrm{OH}$ band at $\sim 3624 \mathrm{~cm}^{-1}$ related to white mica [Farmer and Russell, 1964], and one for the discrete peaks (sharp bands) found between 3000 and $3780 \mathrm{~cm}^{-1}$ (Figure 3). The sum of the curves equal the total absorption spectrum. Only discrete peaks, which can be distinguished from noise, were taken into account. The content of molecular water related to the broad absorption band (Figure 3e) was quantified using the integral molar absorption coefficient function (I) from Paterson [1982]: $I=50(3780-v)$ where $v$ is the wave number in $\mathrm{cm}^{-1}$ and $/$ is in units of $\mathrm{L} \mathrm{cm}^{-2} \mathrm{~mol}^{-1} \mathrm{H}$. The content (in mol H/l) is derived as the integral $\int K(v) / 50(3780-v) d v, K(v)$ is the absorbance at $v$ in $^{\mathrm{cm}^{-1}}$. Molar ppm $\mathrm{H}$ or $\mathrm{H} / 10^{6} \mathrm{Si}$ are obtained through multiplication by a factor of 22,600 . The water content from sharp $\mathrm{OH}$ bands (Figure 3f) in the range between 3000 and $3780 \mathrm{~cm}^{-1}$ was determined using the integral molar absorption coefficient $\left(56,000 \mathrm{~L} \mathrm{~cm}^{-2} \mathrm{~mol}^{-1} \mathrm{H}_{2} \mathrm{O}\right)$ from Kats [1962].

Some minor variation of sharp $\mathrm{OH}$ bands can be expected due to their anisotropy relative to the quartz $\mathrm{c}$ axis and the use of unpolarized IR radiation for grains of varying orientations. However, the larger broad $\mathrm{OH}$ absorption band is expected to be isotropic [Aines and Rossman, 1984]. The band at $3624 \mathrm{~cm}^{-1}$ related to $\mathrm{OH}$ absorption of white mica inclusions is not included for determination of the integral absorbance related to water in quartz. The total water content is given by the sum of the quantities derived from discrete peaks and the broad absorption band.

Care must be taken in comparing the absolute values of hydrogen contents of quartz reported here and in the literature. Apart from different calibrations that have been applied, water is sometimes given in ppm, without indicating whether this represents weight ppm $\mathrm{H}_{2} \mathrm{O} / \mathrm{SiO}_{2}$ or $\mathrm{H} / 10^{6} \mathrm{Si}$ (related by a factor of 6.67 , or $1 \mathrm{wt} \% \mathrm{H}_{2} \mathrm{O}$ equals $66,666 \mathrm{H} / 10^{6} \mathrm{Si}$ ). Water contents from the literature are given in Table 1 as original values in $\mathrm{H} / 10^{6} \mathrm{Si}$ and are also recalculated for a common calibration [Paterson, 1982], 


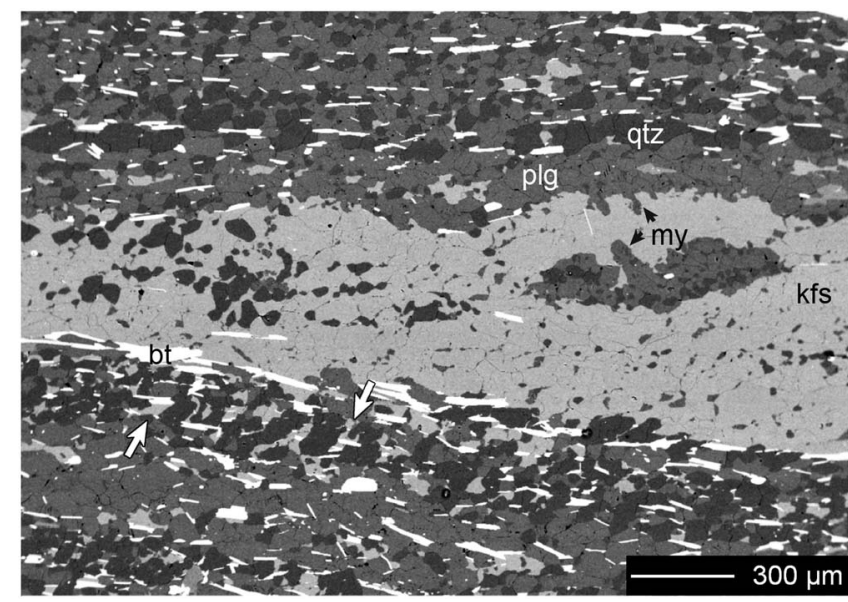

Figure 5. Microstructure of the feldspar-mica matrix: SEM-backscatter electron images of a recrystallized K-feldspar ( $k f s)$ layer with some quartz (qtz) and oligoclase (plg) grains. The matrix around the layer is composed of a homogeneous phase mixture of quartz, plagioclase, K-feldspar and biotite (bt). Myrmekites form in the center as well as at the boundary of the layer (black arrows) and coarsen subsequently. Individual flakes of biotite flakes are homogeneously distributed mixtures of K-feldspar and biotite occupy areas between quartz grains (white arrows). assuming that the major contribution of water related IR absorption originates from a broad absorption band, centered at $3400 \mathrm{~cm}^{-1}$. A factor of 1.9 was used to convert from values which were derived using the calibration of Kats [1962], a factor of 0.8 for those values originating from the calibration of Stipp et al. [2006].

Average spectra for raw data and the fitted Gaussian curves are derived as the quotient of the sum of the thickness-normalized spectra or curves and the number of curves. For some measurements samples Tr3-1 and Tr3-3 have been heated for $24 \mathrm{~h}$ at $120^{\circ} \mathrm{C}$ to reduce water bound at open cracks and the sample surface.

\section{Results}

\subsection{Microstructural Observations}

Primary magmatic minerals are quartz, microperthitic K-feldspar, plagioclase, brown biotite, white mica, and opaques. Magmatic single quartz grains are large, $\sim-10 \mathrm{~mm}$ in diameter. Some magmatic quartz grains show low-angle boundaries, often parallel to the trace of the $c$ axis (Figure 4 a), and some grains show chessboard pattern. Recrystallized quartz grains form at the margins or within magmatic grains leading to quartz aggregates that are entirely recrystallized (Figure 4b). Recrystallized quartz grains are identified by their microstructure, most easily by coarse lobes, which irregularly bulge into magmatic quartz grains. Highly deformed quartz aggregates have large aspect ratios and may thin down to layers only a few grains wide (Figure 4c).

Magmatic K-feldspar grains form large idiomorphic crystals; porphyroclasts are internally dissected by mixtures of fine-grained oligoclase (An20) and quartz. The remaining K-feldspar grains show cross-hatched fine perthite lamella. Fine-grained K-feldspar $(10-30 \mu \mathrm{m})$ forms along the rims and produces tails, with the individual grains being dispersed with other phases, forming a polymineralic matrix (Figure 5). Myrmekites replace K-feldspar clasts and are occasionally found within K-feldspar tails. Magmatic plagioclase is only preserved as relict inclusions inside K-feldspar. Plagioclase in the matrix of the Truzzo meta-granite is completely recrystallized and has a higher Ca content than the original magmatic plagioclase, probably representing grains that recrystallized during high-temperature conditions from an early alpine high-pressure assemblage. The grain size of plagioclase is $\sim 10-40 \mu \mathrm{m}$. Magmatic biotite has a brown color and contains abundant inclusions of opaques. Recrystallized biotite forms around magmatic biotite and dispersed between the other minerals. Recrystallized grains are inclusion free and show the same brown color as the magmatic grains. At low strain, biotite forms layers and polycrystalline aggregates, whereas at high strain it occurs as single, dispersed grains in the polymineralic matrix (Figures 2 and 5).

Additional phases include white mica, sometimes intergrown with magmatic biotite or dispersed in the matrix together with plagioclase. Idiomorphic garnet $(\mathrm{d} \sim 200 \mu \mathrm{m})$ grows within folia of recrystallized biotite or inside plagioclase aggregates rimmed by biotite. Clinozoisites or epidotes are rarely found within the feldspar mixtures and in mica domains. Other accessory minerals include idiomorphic apatite and zircon.

\subsection{Fluid and Solid Inclusions}

Magmatic quartz grains locally contain abundant primary or pseudo-primary fluid and solid inclusions (Figure 6). Fluid inclusions occur in clouds and in few places as trails that decorate healed cracks. Clouds of dispersed fluid and solid inclusions occur exclusively in magmatic grains (Figures $6 a$ and $6 \mathrm{~b}$ ). Fluid inclusions have 

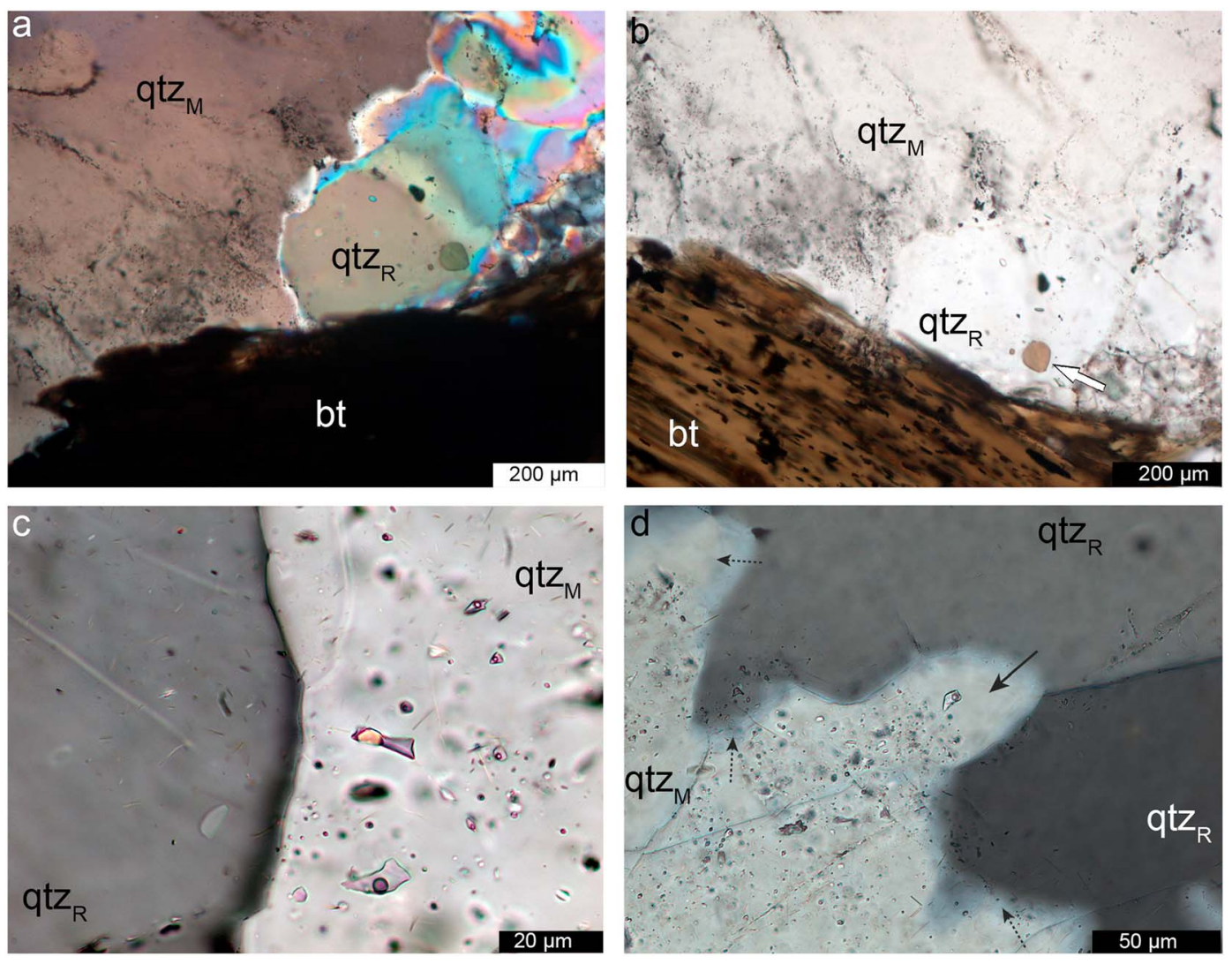

Figure 6. Grain boundary migration and inclusions: (a) Micrograph of a magmatic quartz grain (qtz $\mathrm{z}_{\mathrm{M}}$ ) adjacent to a large magmatic biotite (bt). Note the clouds of solid and fluid inclusions in the magmatic grains, which are absent in a newly grown, recrystallized quartz grain $\left(\mathrm{qtz}_{\mathrm{R}}\right)$. (b) Same as Figure 6a under plane polarized light. Euhedral biotite grains grew along the grain boundary of the recrystallized grain (arrow). (c) Detail of a magmatic grain (right) with solid and fluid inclusions and a recrystallized grain (left) with only minor solid inclusions. Needles are white mica and possibly rutile. (d) Detail of a magmatic grain with a high fluid inclusion density (light, lower left) and two recrystallized grains that are free of inclusions. Late fluid inclusion trails may cut across the grain boundary. Small region in the convex lobe of the grain boundary of the magmatic grain devoid of fluid inclusion indicates a reversal of the direction of the grain boundary migration (black arrow). Stippled arrows indicate where grain boundaries are inclined with respect to the thin section surface. Cross-polarized light (Figures $6 \mathrm{a}$ and $6 \mathrm{~b}$ ) is a taken from a thick section.

variable shapes ranging from negative crystal shapes to irregular, stretched or decrepitated shapes (Figure 6c). In the larger inclusions, a liquid and a $\mathrm{CO}_{2}$-rich gas phase can be identified. In contrast to clouds of fluid inclusions, trails of fluid inclusion may cut across grain boundaries and may occur in both, magmatic and recrystallized grains (Figure 6d).

Most solid inclusions in magmatic and recrystallized grains are mica flakes and to a lesser extent rutile needles, commonly less than $5 \mu \mathrm{m}$ in length (Figures $6 \mathrm{c}$ and $6 \mathrm{~d}$ ). Magmatic quartz grains show the smallest inclusion size, and optically clear grains can contain inclusions below $1 \mu \mathrm{m}$ size. Most recrystallized quartz grains are free of very small mica inclusion. Solid inclusions, coarser than those within the magmatic grains, occur along grain boundaries of recrystallized grains adjacent to the magmatic quartz grains (e.g., euhedral brown biotite; Figures $6 \mathrm{a}$ and $6 \mathrm{~b}$ ). From the convexity of the grain boundaries, the direction of migration can be deduced, generally indicating a replacement of the magmatic grains by recrystallized grains with no or very few fluid inclusions (Figure 6c). However, there are instances where reversals can be observed; parts of the boundary that have moved into a fluid inclusion-rich grain seem to move back leaving behind a fluid inclusion free lobe (Figure 6d).

\subsection{Quartz Microstructures and Crystallographic Preferred Orientation}

Quartz aggregates deformed heterogeneously within the polymineralic matrix. The elongation of quartz aggregates is variable, both inside the shear zones and in the low-strain domains. In the central part of the shear zone (for example, in sample Tr3) the aspect ratios of adjacent quartz aggregates vary between 1.5 and $>15$. 


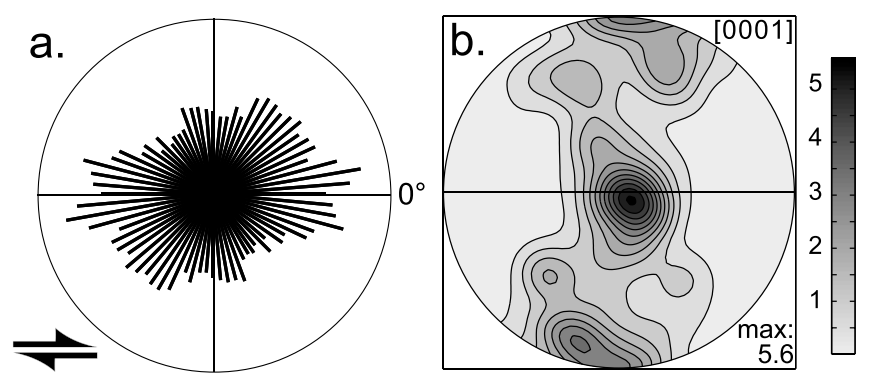

Figure 7. Dislocation creep texture and fabric: (a) Surface orientation density function and (b) $c$-axis pole figure of recrystallized quartz in shear zone, corresponding to layer in Figure 4c. to the shear zone boundary. Most recrystallized quartz grains have lobate grain boundaries; island structures and leftover grains can be recognized. Some recrystallized grains contain isolated low angle boundaries (Figures $4 \mathrm{~b}$ and $4 \mathrm{c}$ ).

In the entirely recrystallized but weakly deformed quartz aggregates, the grain diameters range between 350 and $1000 \mu \mathrm{m}$, with a modal value of $600 \mu \mathrm{m}$, while in the highly deformed quartz aggregates, the grain diameters range between 30 and $550 \mu \mathrm{m}$ with a modal value of around $250 \mu \mathrm{m}$. In the latter case, many grains may be pinned at the aggregate boundaries.

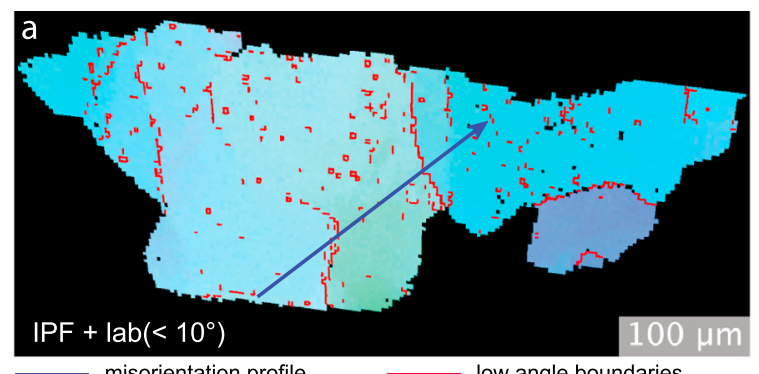

misorientation profile
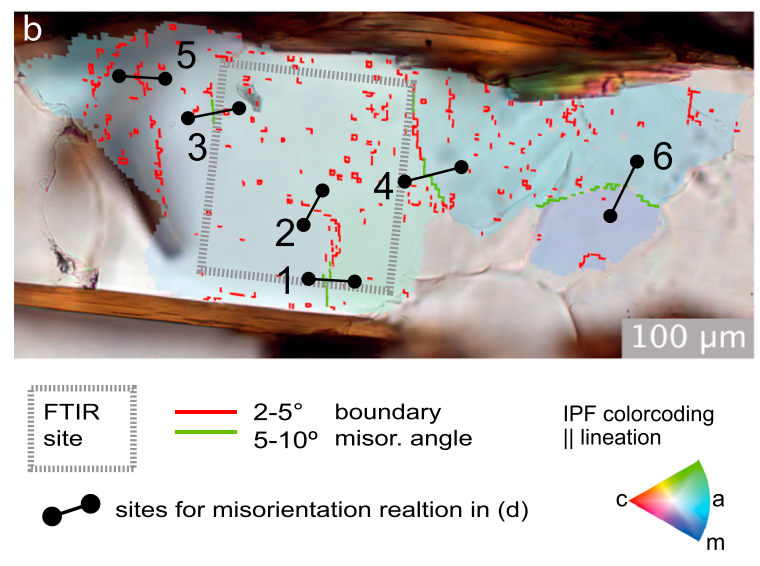

C misorientation profile:

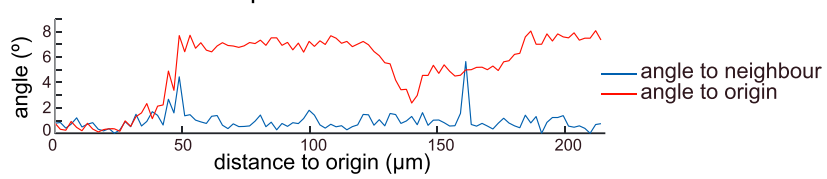

d misorientation axes (crf):

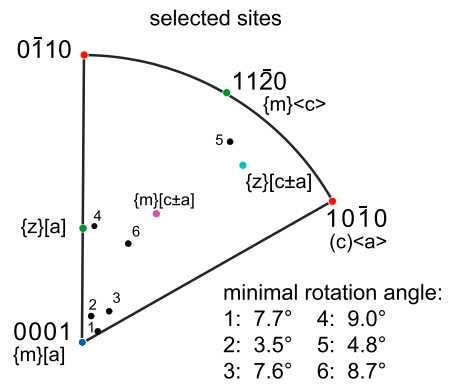

all LABs: $2-10^{\circ} \quad$ all LABs: $5-10^{\circ}$

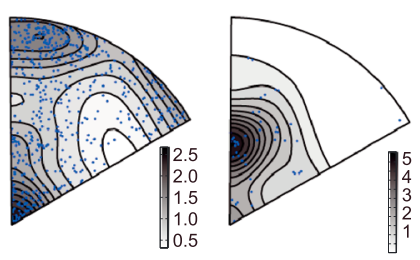

e pole figures:

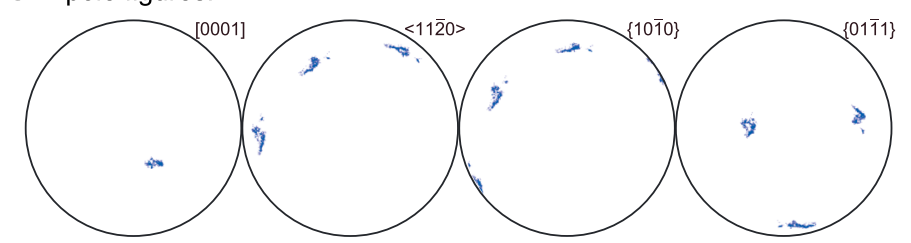

Figure 8. Low-angle boundaries in a dry, recrystallized quartz grain (see Figure 8 e for spectrum Tr1-4a_30, which corresponds to $\sim 30 \mathrm{H} / 10^{6} \mathrm{Si}$ ): (a) EBSD-derived orientation image using inverse pole figure (IPF) color-coding (with respect to the lineation). Low-angle boundaries (LAB $<10^{\circ}$ ), the trace of the misorientation profile (c) and look-up table of IPF color-coding are indicated. (b) Light micrograph overlain with orientation image of Figure 8a. The area of acquisition of FTIR spectrum, low-angle boundaries, and sites used for misorientation determination across LABs are indicated. (c) Misorientation profile showing misorientation angle with respect to neighbors and with respect to the origin of the profile. (d) IPF of misorientation axes derived from orientation pairs in Figure $8 \mathrm{~b}$. Rotation axes expected for edge dislocations forming tilt boundaries of popular slip systems in quartz are indicated. Contoured IPFs of misorientation axes with rotation angles $>2^{\circ}$ and $>5^{\circ}$ from the entire grain. Contours in multiples of uniform distribution. (e) Pole figures derived from all measurement from within the grain shown in Figure 8 a. 

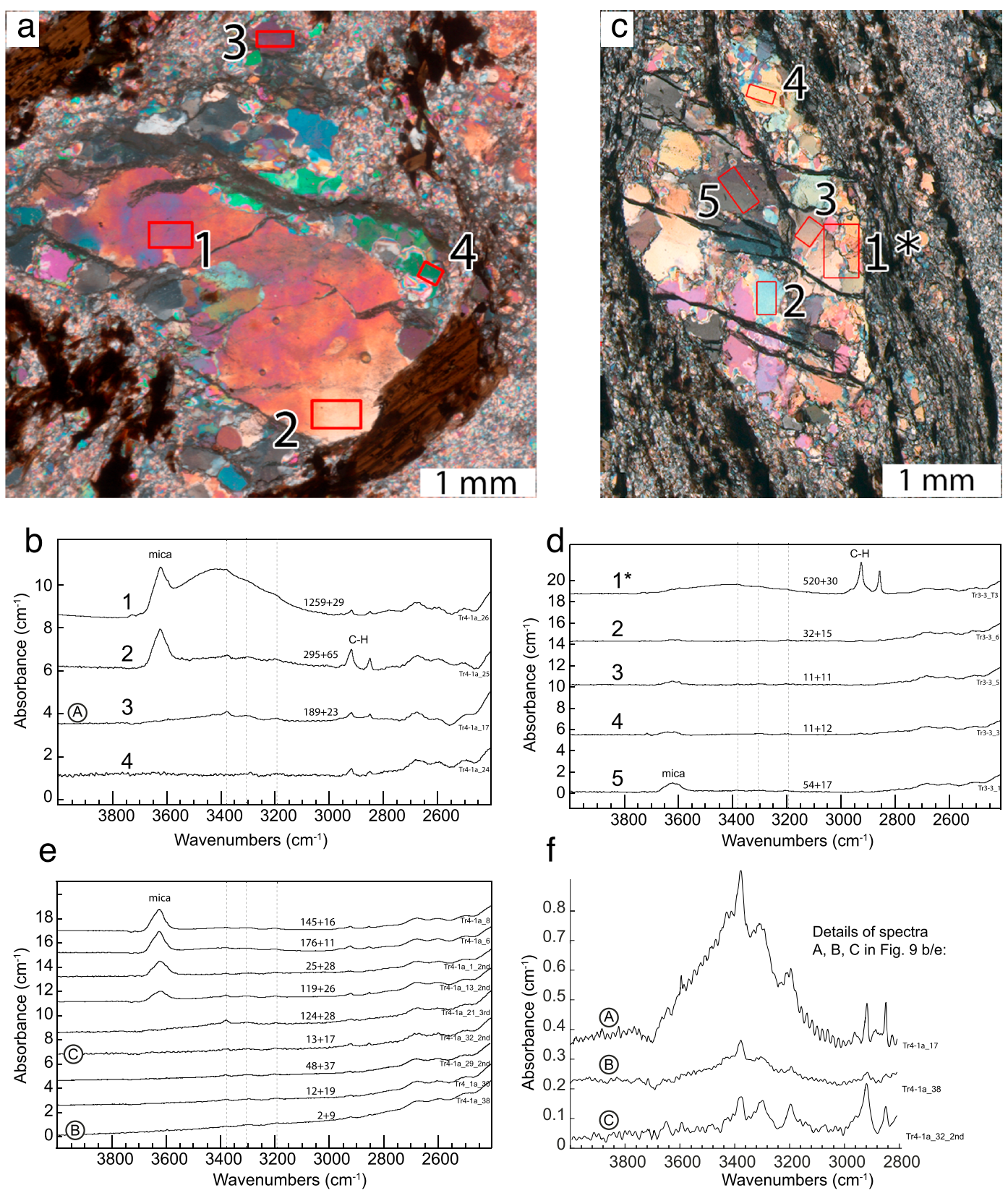

Figure 9. FTIR results: (a) Micrograph showing a quartz aggregate composed of a magmatic grain with recrystallized grains at the margins (crossed polarizers, $170 \mu \mathrm{m}$ thick section). (b) Spectra from inclusion rich (1) and inclusion poor (2) areas in the magmatic grain. Spectra (3) and (4) were collected from recrystallized grains. Magmatic grains show a white mica-related peak (at $3624 \mathrm{~cm}^{-1}$ ), irrespective of the broad absorption band around $3400 \mathrm{~cm}^{-1}$. Frames indicate sites of FTIR measurements producing the spectra shown in Figure $9 \mathrm{~b}$. (c) Micrograph of a quartz aggregate composed of predominantly recrystallized grains (crossed polarizers, $140 \mu \mathrm{m}$ thick section).. (d) FTIR spectrum (1) obtained from an area including grain boundaries and cracks after drying the sample at $120^{\circ} \mathrm{C}$ for $24 \mathrm{~h}$. Spectra (2) to (5) are generally flat and only show variation in the $3624 \mathrm{~cm}^{-1}$ peak. Frames indicate sites of FTIR measurements producing the spectra shown in Figure $9 \mathrm{~d}$. (e) Characteristic spectra of clear magmatic and recrystallized grains. Spectra of both groups can be considered flat but magmatic grains show the mica related $3624 \mathrm{~cm}^{-2}$ peak. Stippled lines at 3195, 3305, and $3380 \mathrm{~cm}^{-1}$. (f) Spectra A, B, and C from Figures $9 \mathrm{~d}$ and $9 \mathrm{e}$ displayed with a higher resolution of absorbance.

In the highly deformed quartz aggregates, recrystallized quartz grains show a very weak particle shape fabric with a bulk axial ratio (b/a) of 0.83 , situated at $5^{\circ}$ with respect to the foliation. The rose diagram of the surface orientation distribution function has a weakly monoclinic geometry and a maximum close to the lineation and a smaller maximum at $\sim 75^{\circ}$ (Figure $7 \mathrm{a}$ ). The quartz $c$-axis pole figure is composed of a girdle subnormal 


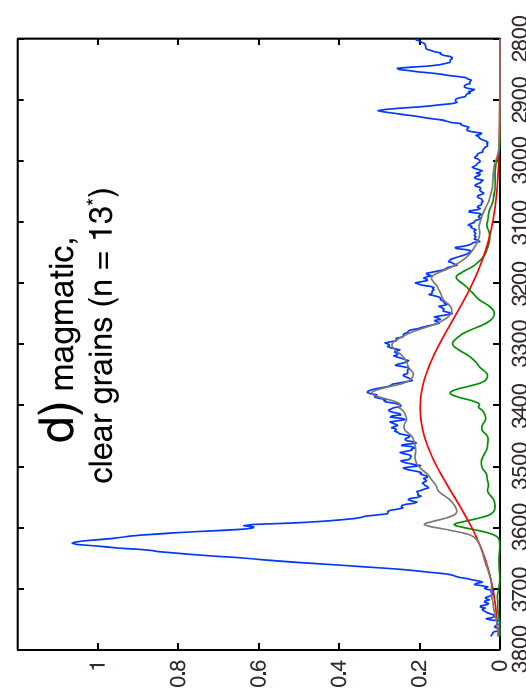

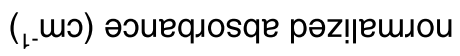
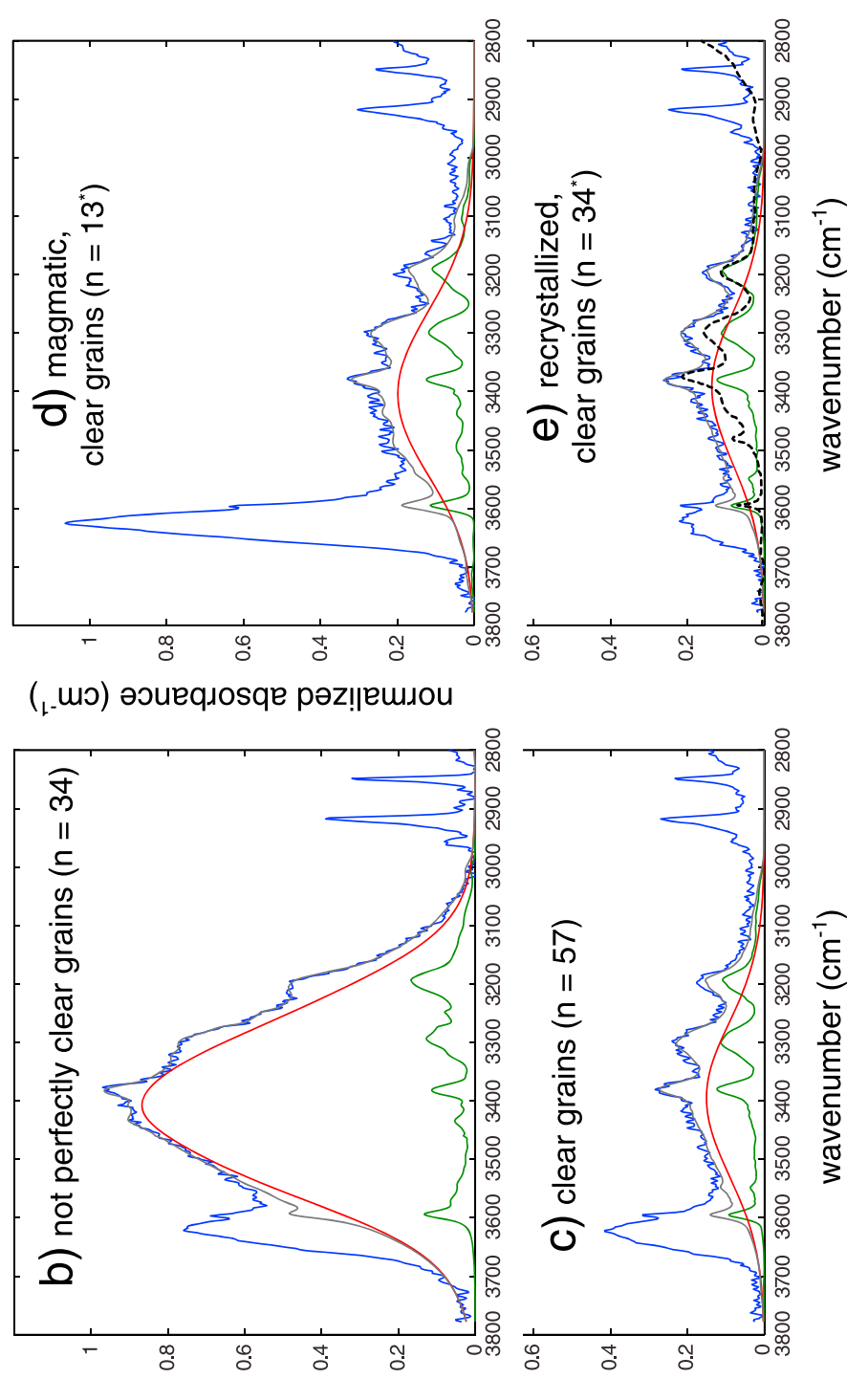

(
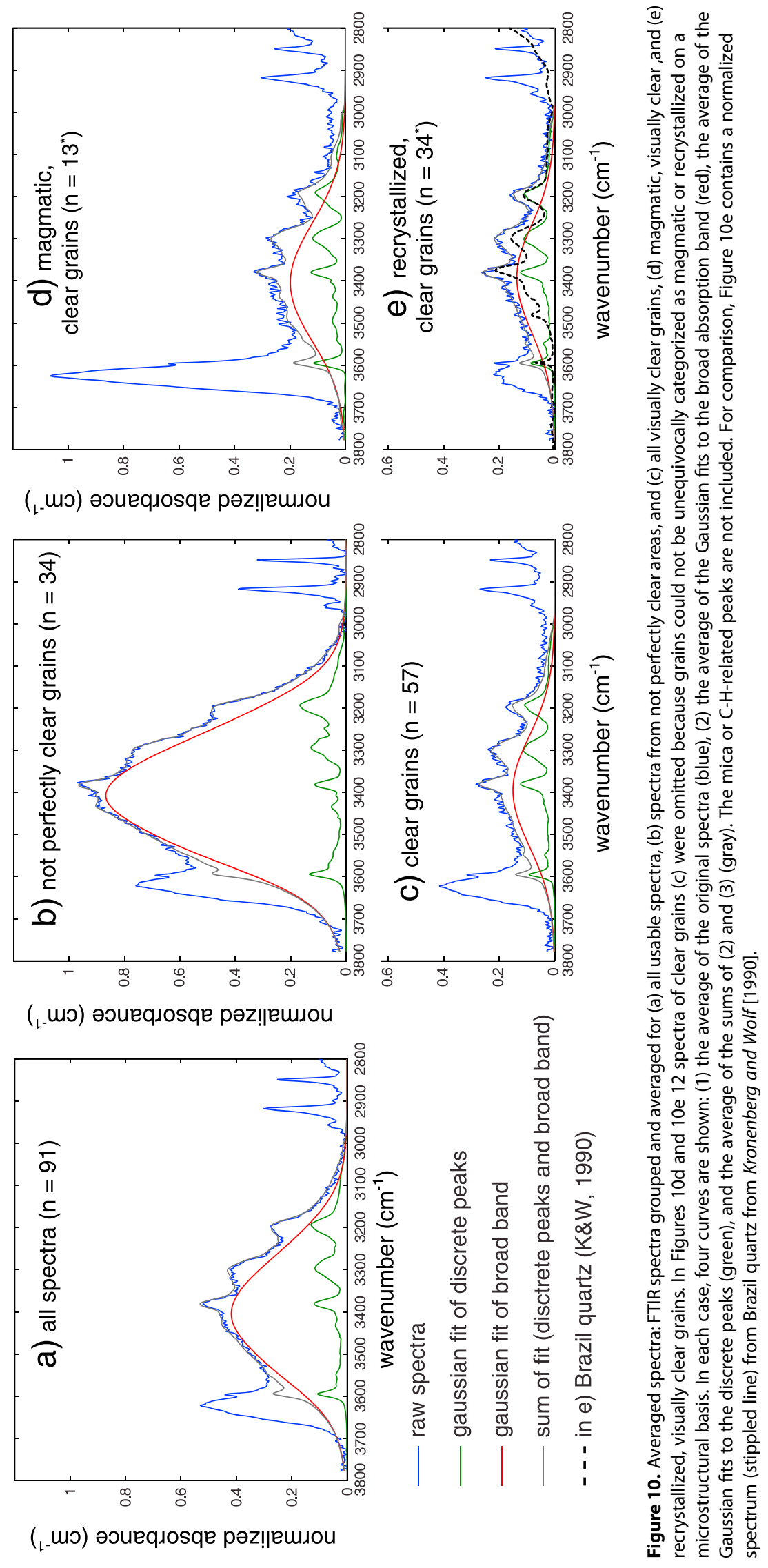

( 
a

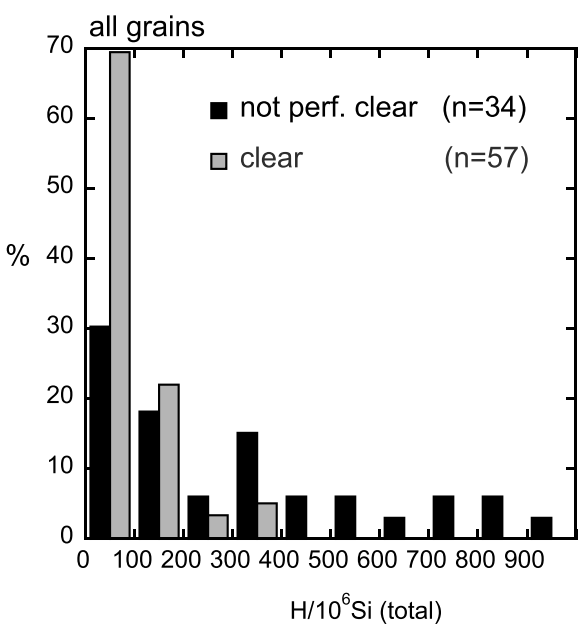

C

clear grains: intracrystalline water only

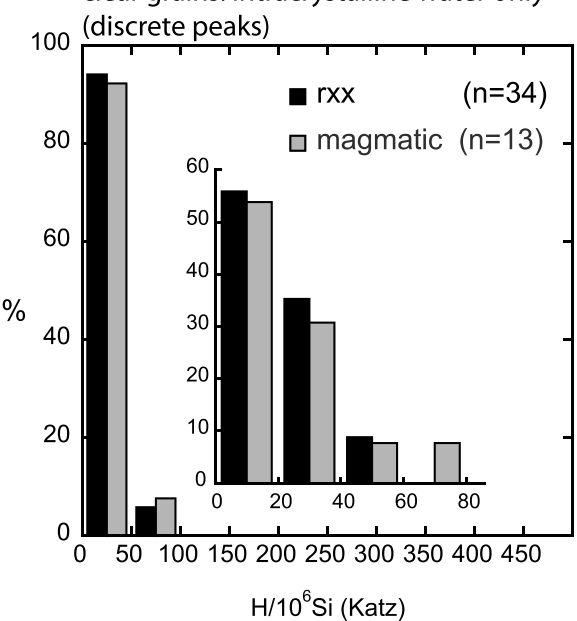

b

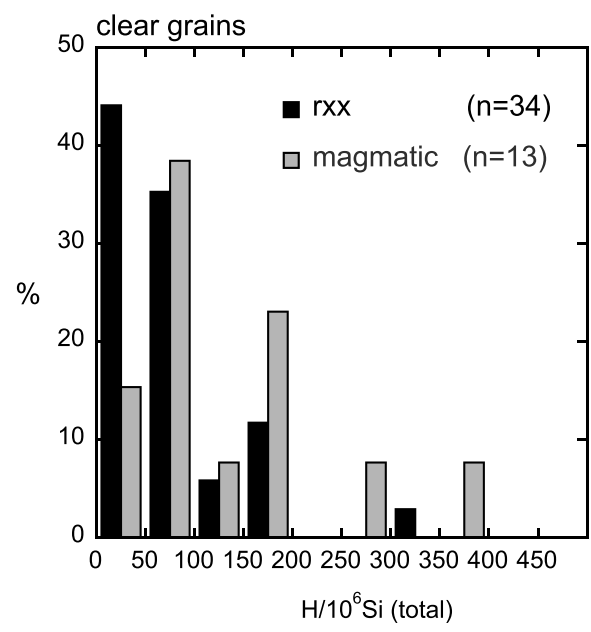

d

clear grains: molecular water only

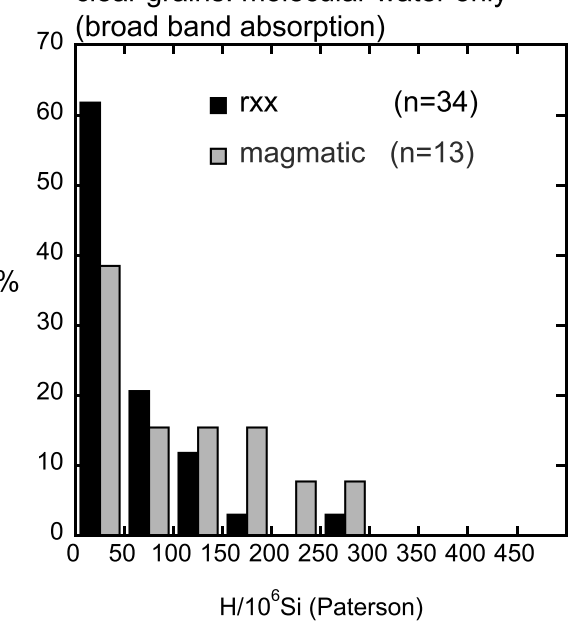

Figure 11. Quantification of water content: (a) Histograms of the total water content calculated as the sum of molecular water (broad absorbance band using the calibration of Paterson [1982]) and $\mathrm{H} / \mathrm{OH}$ species (discrete peaks, using the calibration of Kats [1962]) for clear and not perfectly clear grains. (b) Histogram of quantities for recrystallized (rxx) and magmatic, clear grains. Grain populations are the same as used in Figure 10. (c) Histogram of intracrystalline water content in magmatic and recrystallized, clear grains; inset shows the data for narrower bins. (d) Histogram of the molecular water content in magmatic and recrystallized grains. Units are given in $\mathrm{H} / 10^{6} \mathrm{Si}$.

to the layering with peripheral and central maxima (Figure 7b); occasionally, some aggregates yield a single maximum subparallel to the lineation.

EBSD mapping of some recrystallized grains that have been measured by FTIR reveals a low density of boundaries with misorientation angles of $<10^{\circ}$. As an example we show changes of crystal orientation across these boundaries, expressed by a rotation axis and a rotation angle for an individual grain (Figures 8a-8c). Misorientation axes are determined across low-angle boundaries and also with respect to all neighboring measurements (Figure 8d). On account of their uncertainty, misorientation axes with a corresponding misorientation angle of $<2^{\circ}$ are not plotted. In the grain shown in Figure $8 \mathrm{~b}$, the rotation axis of one low-angle boundary (sites 1 and 2) is very nearly coincident with the $[c]$ axis, another close to the secondary rhomb (pi) (site 4). Misorientation axes across the selected low-angle boundaries are largely consistent with all misorientation axes encountered inside the grain. Axes for misorientation angles of $2-5^{\circ}$ show slightly higher concentrations close to the $a$ axes. The pole figures for $\langle\mathrm{a}>,\{\mathrm{m}\}$, and $\{\mathrm{z}\}$ show a major spread around the $[c]$ 
Table 2. Quantification of Water From Selected Spectra in Comparison to Brazil Quartz

\begin{tabular}{lccc} 
Sample & $\begin{array}{c}\mathrm{H} / 10^{6} \text { Si Using Kats [1962] } \\
\text { for Entire Spectrum }\end{array}$ & $\begin{array}{c}\mathrm{H} / 10^{6} \text { Si by Current } \\
\text { Method }\end{array}$ & $\begin{array}{c}\text { Absorbance at } \\
\sim 3380 \mathrm{~cm}^{-1}\end{array}$ \\
\hline TR4-1a-12 & 140 & $106+22$ & 0.61 \\
TR3-1n_8 & 170 & $270+23$ & 0.68 \\
TR3-1n_11 & 20 & $2+8$ & 0.20 \\
TR3-3_6 & 30 & $32+15$ & 0.125 \\
[Kronenberg and Wolf, 1990]: crystal A-1 $^{\mathrm{a}}$ & $25-90$ & & $0.2-0.4$ \\
[Blacic, 1975]: crystal A-1 $^{\mathrm{a}}$ & 10 & & $\sim 0.26$ \\
\hline
\end{tabular}

${ }^{\mathrm{a}}$ Spectra of clear, recrystallized grains, representative of the range of encountered absorbances. $\mathrm{H} / 10^{6} \mathrm{Si}$ obtained by current method; values are obtained from broad absorbance band + discrete peaks.

Brazil quartz.

direction and a minor spread around $<\mathrm{a}>$ and $\{\mathrm{z}\}$ (Figure $8 \mathrm{e}$ ). These observations are consistent with most grains analyzed by EBSD.

\subsection{Fourier Transform Spectroscopy (FTIR)}

FTIR spectra were acquired on magmatic and recrystallized quartz grains. Figure 9 shows several IR absorption spectra for a partially recrystallized quartz aggregate (Figures 9a and 9b) and a fully recrystallized aggregate (Figures $9 c$ and $9 d$ ). Three different types of spectra can be distinguished. (1) Completely flat spectra: these do not show detectable $\mathrm{OH}$ absorption peaks above noise. (2) Spectra with detectable discrete $\mathrm{OH}$ peaks: discrete peaks are observed at 3195, 3205, 3305, 3371-3380, 3483, and $3596 \mathrm{~cm}^{-1}$ with the most commonly observed peaks at 3195,3305 , and $3380 \mathrm{~cm}^{-1}$. Discrete peaks are typically very small with thickness-normalized absorbances of $<0.2 \mathrm{~cm}^{-1}$ (e.g., Figure 9f). (3) Spectra with a broad OH absorption peak between 3000 and $3800 \mathrm{~cm}^{-1}$, centered at $3400 \mathrm{~cm}^{-1}$ (e.g., Figure 9b, spectra 1-3 and Figure 9b, spectrum 1).

Spectra acquired across areas that contain fluid inclusions, grain boundaries or cracks show a broad peak between 3000 and $3800 \mathrm{~cm}^{-1}$ ("not perfectly clear grains"; Figure 9b). No systematic spectral difference between primary magmatic and late fluid inclusion trails has been observed. Spectra of areas with cracks or grain boundaries are lower after heat treatment $\left(24 \mathrm{~h}\right.$ at $\left.120^{\circ} \mathrm{C}\right)$ but are never flat (Figure $\left.9 \mathrm{~b}\right)$.

Averaged spectra show a decrease of the broad absorption band from not perfectly clear to clear grains (Figure 10). When separating the population of clear grains into recrystallized and magmatic grains, recrystallized grains have the lowest $\mathrm{OH}$ broad band absorbances. Spectra of grains that could not be unequivocally assigned either to magmatic or recrystallized populations were not incorporated into the averaged spectra. There is a systematic decrease in the absorbance of the $3400 \mathrm{~cm}^{-1}$ broad band from large values determined for grains with minute visible inclusions (Figure 10b), to lower absorbances for magmatic but optically clear grains to negligible absorbances for recrystallized clear grains (Figure 10e). In clear quartz grains the thickness-normalized absorbance at $3400 \mathrm{~cm}^{-1}$ deceases to $0.2 \mathrm{~cm}^{-1}$ and $0.17 \mathrm{~cm}^{-1}$ in magmatic and recrystallized grains, respectively. If the superposition of the $3400 \mathrm{~cm}^{-1}$ broad absorption band with the discrete peak around $3380 \mathrm{~cm}^{-1}$ is considered, the total thickness-normalized absorbance at $3400(3380) \mathrm{cm}^{-1}$ is still below $0.34 \mathrm{~cm}^{-1}$. Absorbances of discrete peaks at 3195, 3305, 3380, and $3596 \mathrm{~cm}^{-1}$ remain approximately constant in all populations. The white mica peak at $3624 \mathrm{~cm}^{-1}$ is present in all populations; however, it is most prominent in the magmatic grains (Figures $9 \mathrm{e}, 10 \mathrm{~d}$, and 10e) and smallest in the recrystallized grains.

\subsection{Quantification of Intragranular Water}

Total intragranular H/Si contents determined from optically clear areas are the sum of intracrystalline water and water contained in optically not visible fluid inclusions.

For the clear areas inside grains $(n=57)$ a range of $10-360 \mathrm{H} / 10^{6} \mathrm{Si}$ was determined, while not perfectly clear areas $(n=34)$ display a very wide range of $30-5000 \mathrm{H} / 10^{6} \mathrm{Si}$ (Figure $11 \mathrm{a}$ and Table 2).

IR spectra of clear grains have been further distinguished for magmatic and recrystallized grains (e.g., Figure 10a). Magmatic and recrystallized grains show a similar range in the water content, but most grains with very small values are recrystallized grains (Figure 11 band Table 2). 
Table 3. Summary of the Water Quantities ${ }^{a}$

\begin{tabular}{lcccc} 
Type of Water & Type of Grain & Min & Max & Mean \\
\hline Total (intracrystalline + molecular) & clear & 10 & 360 & 95 \\
& not perfectly clear & 33 & 5059 & 503 \\
Total (intracrystalline + molecular) & recrystallized & 10 & 313 & 72 \\
& magmatic & 47 & 360 & 132 \\
Intracrystalline, only discrete peaks (using Kats [1962]) & recrystallized & 10 & 57 & 21 \\
& magmatic & 11 & 65 & 24 \\
Molecular, only broad band (using Paterson [1982]) & recrystallized & 10 & 282 & 51 \\
& magmatic & 32 & 295 & 108 \\
\hline
\end{tabular}

${ }^{\mathrm{a}} \mathrm{Min}, \mathrm{max}$, and mean values corresponding to the spectra in Figure 10 and histograms shown in Figure 11. Units are in $\mathrm{H} / 10^{6} \mathrm{Si}$.

Histograms of water contents from individual grains are identical for magmatic and recrystallized grains (Figure 11c). However, the histogram of water determined from the broad absorption bands (molecular water) in magmatic grains shows a more uniform distribution than that determined from recrystallized grains showing a shift toward lower values (Figure 11d).

The same relation is evident from the values determined from the averaged fitted curves. Values determined from discrete peaks are identical for recrystallized and magmatic grains with an average of $20-30 \mathrm{H} / 10^{6} \mathrm{Si}$ and maximal values $<70 \mathrm{H} / 10^{6} \mathrm{Si}$. Water contents determined by the broad absorption band at $3400 \mathrm{~cm}^{-1}$ have maximal value of $<300 \mathrm{H} / 10^{6} \mathrm{Si}$. On average, however, the value for recrystallized grains is $\sim 50 \mathrm{H} / 10^{6} \mathrm{Si}$, which is half the value of the clear magmatic grains.

The peak at $3624 \mathrm{~cm}^{-1}$ related to $\mathrm{OH}$ groups in white mica also appears in clear grains, in which no inclusions were identified by low-magnification light microscopy. Most IR spectra of magmatic quartz grains with high mica contents show highly variable water contents. Grains with low white mica contents usually show low intragranular water contents; however, the opposite relation is not supported by the data.

Biotite peaks are very infrequent in the FTIR spectra of recrystallized or magmatic quartz grains; $\mathrm{OH}$ peaks of biotite should occur at wave numbers lower than $3600 \mathrm{~cm}^{-1}$ [Farmer and Russell, 1964], where spectra are flat. Apparently biotite does not occur as fine inclusions, and relatively coarse biotite inclusions are easily identified and avoided during acquisition of the FTIR spectra.

\section{Comparison With Earlier Work}

\subsection{Characteristics of FTIR Spectra}

FTIR spectra obtained inside clear quartz grains of the TGM lack large OH absorption peaks or bands, especially at the broad absorption band centered at $3400 \mathrm{~cm}^{-1}$, which is related to the presence of molecular water [Aines and Rossman, 1984]. The thickness-normalized absorbance at $3400 \mathrm{~cm}^{-1}$ is about $0.34 \mathrm{~cm}^{-1}$ for clear grains, including the superposed $\mathrm{OH}$ peak at $3380 \mathrm{~cm}^{-1}$, and as such indistinguishable from published thickness-normalized absorbances of $0.2-0.4 \mathrm{~cm}^{-1}$ for Brazilian quartz [Kronenberg et al., 1986; Kronenberg and Wolf, 1990] (Figure 10e and Tables 2 and 3). This is in contrast to thickness-normalized absorbances of $\sim 2.5 \mathrm{~cm}^{-1}$ at around $3400 \mathrm{~cm}^{-1}$ for grains of experimentally deformed Heavitree quartzite [Post and Tullis, 1998] and 3-25 $\mathrm{cm}^{-1}$ for quartz in naturally deformed rocks (Eriboll quartzite [Kronenberg and Wolf, 1990], Sambagawa metamorphics, and Median Tectonic Line mylonites [Nakashima et al., 1995]). In some of these cases, the thickness-normalized absorbances are very high because the measurements include water in intragranular fluid inclusions and, in some cases, fluid trapped at grain boundaries. Vacuum-dried Heavitree quartzite still has thickness-normalized absorbances of $>1 \mathrm{~cm}^{-1}$ [Post and Tullis, 1998].

The sharp peak triplet at wave numbers of 3195,3305 , and $3380 \mathrm{~cm}^{-1}$ of quartz from the TGM shows the same character as the sharp peaks found in the spectra of Brazil quartz [Kronenberg and Wolf, 1990] (Figure 10e). A prominent peak at $3371 \mathrm{~cm}^{-1}$ has been related to a charge compensating $\mathrm{OH}$ defect near Al substitutions for $\mathrm{Si}$, and a peak at $3382 \mathrm{~cm}^{-1}$ is related to $\mathrm{OH}$ near Na defects [Kats, 1962]. The peak at $3380 \mathrm{~cm}^{-1}$ is not assigned definitively according to Aines and Rossman [1984], but may be due to OH defects near Al [Pankrath, 1991; Shinoda and Aikawa, 1993], as suggested as well for the peaks at $3596 \mathrm{~cm}^{-1}[$ Niimi et al., 1999] and $3305 \mathrm{~cm}^{-1}$ [Pankrath, 1991]. 
Al diffusivities in quartz might be very low [Pankrath and Flörke, 1994], and from this point of view, this defect is not likely to play an important role during deformation of quartz. At the other hand, none of these peaks have been assigned with a defect related to hydrolyzed dislocations or any other mobile water related defect, which could be associated with hydrolytic weakening.

\subsection{Water Quantities in Quartz}

Table 1 reports water contents from the literature for quartz from naturally deformed rocks, quartzites, and single crystals used in deformation experiments. (In the following, it will be referred to as the re-calculated values in column 6 of the Table 1). In most cases, the bulk water contents are significantly greater than the intragranular water contents we report for the TGM, which is usually less than $100 \mathrm{H} / 10^{6} \mathrm{Si}$ (Tables 2 and 3 and Figure 11).

In experiments, frequently $>10,000 \mathrm{H} / 10^{6} \mathrm{Si}$ are added to the assembly in order to observe water weakening, and "as-is" experimentally deformed quartzites (without any additional water added) contain several thousands of $\mathrm{H} / 10^{6} \mathrm{Si}$. Similarly, values reported for natural mylonites are usually in the range of several thousands to more than $10,000 \mathrm{H} / 10^{6} \mathrm{Si}$. Most of these FTIR measurements of polycrystalline quartz include water along grain boundaries, cracks, and/or in fluid inclusions. Lower water contents are reported for rocks with a larger grain size [Nakashima et al., 1995; Ito and Nakashima, 2002], also indicating that most of this water is probably intergranular. Even vacuum-dried, polycrystalline quartz samples may contain large amounts of water (Table 1), e.g., $>1000 \mathrm{H} / 10^{6} \mathrm{Si}$ for $\mathrm{BHQ}$ dried at $800^{\circ} \mathrm{C}$ and $6 \mathrm{~Pa}$ for $8 \mathrm{~h}$ [Stipp et al., 2006] related to fluid inclusions and water along grain boundaries.

Intragranular water contents of quartzites are generally lower (Table 1) than the bulk water contents. In naturally deformed rocks, intragranular values are often several hundreds to thousands of $\mathrm{H} / 10^{6} \mathrm{Si}$, while bulk values are always $>1000 \mathrm{H} / 10^{6} \mathrm{Si}$. In quartz rocks used for deformation experiments a similar picture emerges, if not as clearly, with intragranular values being as low as a few hundreds of $\mathrm{H} / 10^{6} \mathrm{Si}$ and bulk measurements of $\gg 1000 \mathrm{H} / 10^{6} \mathrm{Si}$. Brazil quartz single crystals have intragranular water contents of $<100 \mathrm{H} / 10^{6} \mathrm{Si}$, which is largely intracrystalline water, and only synthetic quartz may contain high intragranular water contents of several thousands of $\mathrm{H} / 10^{6} \mathrm{Si}$.

In detail, there is a high degree of variability in each of the data sets. For example, vacuum-dried grains $\left(800^{\circ}\right.$ $\mathrm{C} / 12 \mathrm{~h}$ ) of Heavitree quartzite can contain $130-1250 \mathrm{H} / 10^{6} \mathrm{Si}$ with an average of $450 \mathrm{H} / 10^{6} \mathrm{Si}$ and grains of experimentally deformed Heavitree quartzite with an addition of $20,000 \mathrm{H} / 10^{6} \mathrm{Si}$ to the sample assembly have contents of $260-4480 \mathrm{H} / 10^{6} \mathrm{Si}$ with an average of $1550 \mathrm{H} / 10^{6} \mathrm{Si}$ [Post and Tullis, 1998]. Similarly, grains of Dongelsberg quartzite [den Brok et al., 1994] show a range of water contents from $<200$ to $3000 \mathrm{H} / 10^{6} \mathrm{Si}$, which do not change on a statistical basis during experimental deformation with $25,000 \mathrm{H} / 10^{6} \mathrm{Si}$ added to the sample assembly. Quartz grains in greenschist facies mylonites are reported to contain $40-2200 \mathrm{H} / 10^{6} \mathrm{Si}$ [Gleason and DeSisto, 2008], and quartz grains from granulite facies rocks exhibit a wide range of water contents, from grains that lack a broad $\mathrm{OH}$ band to grains with $2000 \mathrm{H} / 10^{6} \mathrm{Si}$ [Menegon et al., 2011].

The variability of these intragranular water contents of quartz can be related to variable distributions of fluid inclusions as well as the difficulty to measure intragranular water contents in experimentally deformed quartz due to the small grain size. Similarly, in the present study, FTIR spectra that are obtained across areas with fluid inclusions, cracks, and grain boundaries show a broad absorption band with high water contents of up to several thousands of $\mathrm{H} / 10^{6} \mathrm{Si}$, even after heat treatment, while spectra acquired from optically clear areas show no significant broad absorption band.

\subsection{Availability of Water During Deformation}

The lack of fluid inclusions in recrystallized grain interiors is in stark contrast to locally high densities of fluid inclusions in the magmatic quartz grains, suggesting that they were lost during grain boundary migration recrystallization as the grain boundaries swept the grain interior (Figure 6). Through the destruction of fluid inclusions, the intragranular fluid was expelled from the grain interior and released into the mobile grain boundaries. Low white mica concentrations in recrystallized grains indicate that elimination of solid inclusions might require that grains are swept by grain boundaries several times. The relatively easy removal of fluid inclusions compared with that of solid inclusions by a migrating grain boundary is well documented in naturally deformed quartz [Drury and Urai, 1990; Schmatz and Urai, 2011]. 
In addition to residual white mica inclusions, biotite appears homogeneously dispersed throughout the polymineralic matrix (Figure 5) and grew along grain boundaries of newly recrystallized quartz grains (Figures 6a and 6b). K-feldspar reacted to myrmekite, which requires bulk material transport that would have been facilitated by an aqueous grain boundary fluid [e.g., Phillips, 1980]. Therefore, the microstructures of the TGM appear to have formed at water-present conditions, although the exact quantity cannot be determined. FTIR studies on the intragranular water contents of pyroxenes and plagioclase from dry granulites devoid of hydrous minerals suggest whole rock water contents of about 150-1000 wt ppm $\mathrm{H}_{2} \mathrm{O}$ [Xia et al., 2006], which is more than the postdeformational bulk water content of water-added BHQ [Stipp et al., 2006]. Given that the Truzzo meta-granite contains abundant and stable biotite and white mica, it can be assumed that water was present and available during deformation, at least to the same extent as in water-added deformation experiments.

\subsection{Deformation of Quartz at Low Differential Stress}

Given the low water contents of quartz grains within the TGM, we might expect that deformation occurred at elevated differential stresses. Rocks deformed at middle to lower crustal depths and high temperatures, showing microstructures typical for BLG and SGR recrystallization, which are usually observed for rocks deformed at lower grade conditions, are interpreted to result from water deficient conditions. For example, amphibolite facies rocks studied by Fitz Gerald et al. [2006] exhibit a small recrystallized grain size.

In shear zones of the Truzzo meta-granite, pervasive GBM recrystallization has been found. Toward the centers in the shear zones, quartz aggregates became elongated, and simultaneously, recrystallized grains replaced magmatic grains. The presence of a crystallographic preferred orientationand a monoclinic grain surface ODF (Figure 7) are characteristic of dislocation creep [e.g., Kilian et al., 2011b]. The microstructure of the recrystallized grains (e.g., Figures 4, 6, and 9) is typical for GBM recrystallization [e.g., Stipp et al., 2002] in accordance with the inferred deformation conditions of the TGM of around 550-650 C/0.8-1.3 GPa [Marquer, 1991: Baudin and Marquer, 1993; Huber and Marquer, 1998] and also qualitatively supported by the stability and growth of brown biotite and oligoclase.

All microstructural features indicate that the TGM formed at relatively low differential stresses. Low stresses are implied by dynamic recrystallization by GBM with mean grain sizes that are large [e.g., Derby and Ashby, 1987]. Extrapolating the piezometer by Stipp et al. [2006] would result in differential stresses of $\ll 20 \mathrm{MPa}$. However, this must be regarded as a merely qualitative number because there is no piezometer calibration that can be used for GBM recrystallization and at grain equivalent diameters larger than $120 \mu \mathrm{m}$ [e.g., Shimizu, 2008]. Differential stresses of $<10 \mathrm{MPa}$ were estimated from quartz veins deformed at $\sim 550^{\circ} \mathrm{C}$, which show microstructures comparable to the quartz in the TGM [Mancktelow and Pennacchioni, 2010]. Support for low stresses also comes from the microstructure of the matrix as it is interpreted to form by diffusion creep, i.e., dissolution-precipitation accommodated grain boundary sliding [Kilian et al., 2011a]. Because quartz aggregates deform embedded in a fine-grained polymineralic matrix, differential stresses are expected to be in the range of those imposed by the matrix.

\subsection{Comparison With Natural and Experimental Deformation}

The measured infrared spectra and the calculated intracrystalline/granular water contents of the recrystallized quartz and clear regions of magmatic quartz of the TGM are very similar to those of Brazilian and dry synthetic quartz [Blacic, 1975; Kronenberg et al., 1986]. From this point of view, the quartz of these shear zones must be regarded as dry while only the grain boundaries contained significant amounts of water. To our knowledge, the intragranular water content in the TGM is the lowest value ever reported for rocks deformed under natural conditions. Nevertheless, the microstructures in these highly sheared rocks indicate deformation at low differential stresses. Moreover, we do not observe any microstructures such as, for example, a locally decreased grain size, grains related to bulging recrystallization, or local undulous extinction that suggest an increase in stress with deformation that might be associated with hardening due to losses of intragranular water during recrystallization.

Deformation experiments have repeatedly demonstrated that dry quartz is strong and cannot be deformed plastically to strains larger than $\sim 1 \%$ without brittle failure [e.g., Griggs and Blacic, 1964; Kronenberg and Tullis, 1984; Blacic and Christie, 1984; Cordier and Doukhan, 1989; Post and Tullis, 1998]. The very low intragranular water contents measured in the TGM correspond to the quantities of $\mathrm{OH}$ which are, in theory, sufficient to 
act directly on dislocations ( $\ll 100 \mathrm{H} / 10^{6} \mathrm{Si}$ [Griggs and Blacic, 1965; Paterson et al., 1972; Hirsch, 1981; Hobbs, $1981,1984]$ ). However, they are not compatible with the quantities (greater than thousands of $\mathrm{H} / 10^{6} \mathrm{Si}$ ) that are required to observe water weakening in deformation experiments.

There are various processes observed in deformation experiments that relate considerable amounts of water to mechanical weakening. There is the intragranular water that is present as small fluid inclusions, which link (micro) fracturing, healing, and the production of dislocations [McLaren et al., 1983, 1989; Post and Tullis, 1998; Fitz Gerald et al., 1991; Mainprice and Jaoul, 2009]. At the other hand there is intergranular water which increases the grain boundary mobility [e.g., Tullis and Yund, 1982; Stipp et al., 2006] and is interpreted to cause weakening due to increased recovery rates by faster GBM [Holyoke and Kronenberg, 2013]. There are also additional processes and mechanisms, which have been suggested to account for water weakening in quartz deformation experiments such as stress corrosion cracking [Fitz Gerald et al., 1991], dissolution-precipitation creep [den Brok and Spiers, 1991], or grain boundary sliding [Paterson and Luan, 1990]. While some of those latter mechanisms have been identified, it is uncertain to which extend they play a strain producing role during dislocation creep. More importantly, it needs to be discussed how the experimental evidence of weakening by large amounts of water can be compatible with the results obtained from the TGM.

\section{Discussion}

\subsection{Interpretation of the Role of Water During Quartz Deformation}

The discovery of dry quartz grains in highly sheared rocks, which show indications of deformation by dislocation creep at low differential stresses, poses a challenge to the paradigm that quartz deforms in nature by the same water weakening processes as observed in laboratory experiments. We will attempt to resolve this paradox by approaching it from two sides: first, by assuming that dislocation creep in nature does not require the same high intragranular water contents as in experimental deformation, and second, by assuming that any intragranular water content necessary for dislocation creep is transient and cannot be retrieved from natural samples.

\subsubsection{Very Low Concentrations of Intracrystalline Water During Dislocation Creep in Nature}

One potential solution to the discrepancy between experimental and natural deformation of quartz is that intragranular water contents in nature need not be as large as those in deformation experiments. Very low concentrations of hydrogen defects and complexes were suggested to promote dislocation creep by influencing the rate limiting process, e.g., by nucleation of double kinks [McLaren et al., 1983; Cordier et al., 1994], increasing the dislocation density [Griggs, 1974; McConnell, 1997], increasing dislocation velocities [Kirby and McCormick, 1979; Hirsch, 1981; Cordier et al., 1994; Mainprice and Jaoul, 2009], and facilitating climb by nucleation of dislocation jogs [e.g., Hobbs, 1984; Heggie and Jones, 1986; Paterson, 1989; Cordier and Doukhan, 1989; Cordier et al., 1994]. Synthetic quartz with water contents as low as $\sim 100 \mathrm{H} / 10^{6} \mathrm{Si}$ can be deformed experimentally by dislocation glide as long as strain remains small ( $1 \%$ [Cordier and Doukhan, 1989]). Equilibrium concentrations of simple and extended hydrogen point defects in quartz at PT conditions of the TGM are calculated in the range of $<20 \mathrm{H} / 10^{6} \mathrm{Si}$ [Paterson, 1986] to around $400 \mathrm{H} / 10^{6} \mathrm{Si}$ [Doukhan and Paterson, 1986; McConnell, 1997]. These concentrations must be regarded as crude estimates, and neither the assumed hydrogarnet defect $\left(4 \mathrm{H}^{+}\right.$substitute $\left.\mathrm{Si}^{4+}\right)$ has been definitively demonstrated for quartz [Cordier et al., 1994], nor have the larger concentrations been observed in natural quartz. However, only a few $\mathrm{H} / 10^{6} \mathrm{Si}$ are required to saturate bonds in dislocation cores by disilanol complexes or other extended hydrogen defects [Griggs, 1974; Paterson, 1989]. However, even disregarding the concentration of hydrogen defects related to Al, the very low intragranular water contents measured in quartz of the TGM are still sufficiently high to saturate dislocations at moderate dislocation densities.

Diffusion of water or related defects from the grain boundary along dislocations (pipe diffusion) is most likely important at both experimental and natural time scales [McLaren et al., 1989; Cordier and Doukhan, 1988; Gerretsen et al., 1989; Bakker and Jansen, 1994]. While direct measurements for pipe diffusion of hydrogen and water defects in quartz are not available, Yund et al. [1981] found that pipe diffusion of oxygen in albite can be 5 orders of magnitude higher than oxygen volume diffusion. Assuming that rates of pipe diffusion in quartz are sufficiently rapid, hydrogen defects may produce mobile dislocation kinks and jogs within grain interiors, sourced from fluid films at grain boundaries. Such diffusional transport may be an effective 
weakening process at natural strain rates, while the diffusional distances are too large at experimental strain rates, hence requiring additional weakening mechanisms in experiments. Additionally, the requirements on dislocation nucleation rates in experiment and nature differ because the required time-averaged density of glissile dislocations is loosely proportional to the strain rate of a crystal. Hence, the water-mediated processes increasing the dislocation densities-and the intragranular water content-observed in experiments [e.g., Fitz Gerald et al., 1991], will be of minor importance at high-grade natural conditions.

The observation of subgrain boundaries within dry quartz grains (Figures 4 and 8 ) and significant dry portions of magmatic grains that appear to be deformed without any indications of high stress sites can support the feasibility of dislocation climb and glide at the low intragranular water concentrations of the TGM. Accordingly, theory and observations permit that essential mechanisms for dislocation creep seem to be possible with very small amounts of intragranular water. As long as grain boundaries are mobile due to intergranular water, deformation may occur with low differential stresses at natural strain rates.

\subsubsection{Transient Water}

Another possible explanation for the low intragranular water contents measured in quartz of the TGM is that water contents have changed with time and that the measured water contents are not representative of water contents during deformation.

Intragranular water contents and distributions of fluid inclusions can be altered by a number of processes. Brittle fracturing and crack healing can introduce fluid inclusions into grain interiors [Rovetta et al., 1986; Kronenberg et al., 1990; Tarantola et al., 2010]. In experiments, small fluid inclusions are observed to act as sources of dislocations [Fitz Gerald et al., 1991], similar to fluid inclusions precipitated within synthetic quartz [McLaren et al., 1983, 1989]. The removal of intragranular water by sweeping grain boundaries is documented in the TGM by the inclusion-free recrystallized grains and GBM microstructures. Thus, a mechanism of cyclic fracturing, water influx, healing, water-related weakening, subsequent removal of intragranular water, and anew hardening etc. could account for the discrepancy between our observations and deformation experiments.

However, there is an observational bias. In our samples, we see evidence of the removal of fluid inclusions from magmatic grains, but none of the re-introduction of water into the grain interior. The magmatic grains preserve evidence of early intragranular water, and the removal of these fluid inclusions by sweeping grain boundaries can be observed in many instances. In contrast, no traces of (repeated) re-introduction of intragranular fluid inclusions or any transient water content have been found so far. As a matter of fact, we have not found a single recrystallized grain with substantial amounts of primary intragranular water or local high-stress sites at a grain scale; i.e., we have no preserved evidence that new fluid inclusions or any transient water were re-introduced into the grains during deformation. Therefore, one would have to conclude that all traces of transient water are removed by static recrystallization after the last deformation increment. Some observations such as the dynamic microstructure including low-angle boundaries and clear but deformed parts of magmatic grains are difficult to explain within the scope of static recrystallization, which would be required to remove the evidence of transient water.

\subsection{Implications for Experiments and Nature}

The terms "wet" and "dry" quartz can be misleading, and in the literature they are used in different ways. From the point of view of deformation experiments, dry quartz may often contain up to a few $100 \mathrm{H} / 10^{6} \mathrm{Si}$ and wet quartz 10 to 100 times more water, although it is not necessarily clear that these values apply to the bulk water content of quartz rocks. Judging from experiments, dry quartz is held to be strong and wet quartz is believed to be capable of dislocation creep. Extrapolating from experiments to nature and from quartz to crustal rocks, the crust is assumed to be strong if it is dry and weak if water is present. Natural, petrologically dry rocks can still contain $>1000 \mathrm{H} / 10^{6} \mathrm{Si}$ [e.g., Xia et al., 2006]—qualifying them as wet from the rheological-experimental point of view (Table 1), while quartz grains in the TGM are basically dry inside a wet rock. Accordingly, the values associated with wet and dry differ for many situations, and it is useful to return to the concept of intragranular, intracrystalline, intergranular, and bulk water contents.

Several inferences can be drawn from observations in naturally deformed rocks. The difference in microstructures of the TGM and the so-called "water-deficient" mylonites can be interpreted to result from a limited grain boundary mobility if intergranular water is not sufficiently present [Pennacchioni and Cesare, 1997; Mancktelow and Pennacchioni, 2004]. A low grain boundary mobility may result in a low grain boundary 
velocity, and instead of GBM recrystallization, SGR or BLG recrystallization will become the dominant recovery mechanism, which has to counterbalance dislocation production rates at conditions where nucleation, multiplication, glide, and climb of dislocations are easy due to high temperatures and geologic strain rates. For example, in the water-deficient, high-temperature mylonites, no spatial correlation of small fluid inclusions and dislocations was observed [Fitz Gerald et al., 2006], implying that dislocation generation might not be as intimately tied to (micro) fracturing as in many deformation experiments.

An increase in strength at high-temperature conditions can be interpreted as a suppression of the fastest recovery mechanism and may not be related to any extraordinarily low intragranular water contents, which is supported by our results. Accordingly, relating a low intragranular water content in naturally deformed rocks with water absent conditions or strong quartz is not advised.

The ability to extrapolate mechanical results of deformation experiments to nature depends critically on the activation of the same rate limiting processes of deformation and recovery in nature and the corresponding experiments. Microstructures typical for BLG and SGR recrystallization or crystal bending produced in deformation experiments are comparable to those encountered at lower temperature, natural conditions, and it can be assumed that deformation processes take place at similar proportions in nature and experiment [e.g., Hirth and Tullis, 1992; Stipp et al., 2002]. Notably, bulk water contents in greenschist facies mylonites are large, much as they are in experimentally deformed quartzites (Table 1). Given that the individual contribution of intergranular and intragranular water is similar, it can also be assumed that the water-aided weakening mechanisms, which require large amounts of water found in experiments, may equally take place in nature [e.g., Kronenberg et al., 1990; Bakker and Jansen, 1994]. Under those conditions, experimentally derived flow laws can be used to estimate rheology in nature.

However, at natural high-temperature conditions where GBM recrystallization dominates the microstructure, it is questionable if the extrapolation of flow laws is appropriate. Deformation experiments on quartzites without any addition of pinning particles at $1100^{\circ} \mathrm{C}$ and low strain rates of $10^{-7} \mathrm{~s}^{-1}$ result in a foam structure [Stipp et al., 2006] instead of grain scale lobate boundaries and do not resemble microstructures produced by dynamic recrystallization in nature. The microstructures of dislocation creep accompanied by GBM recrystallization have not been replicated in deformation experiments. Thus, it is challenging to ponder the roles of water and hydrogen defects and their necessary concentrations for water weakening in nature and experiments. Our results indicate that it may well be that the extent of water weakening needed to explain natural deformation of quartz by dislocation creep need not to be as large as in experiments.

Hence, during extrapolation from laboratory to natural conditions, besides the time-temperature trade-off for the creep rate limiting process observed in experiments, also the temperature and water dependency for all potentially rate limiting processes, must be taken into account. For example, experiments indicate that wet and dry silica diffusion in quartz and diffusion in an intergranular fluid have different activation energies (137 and $178 \mathrm{~kJ} / \mathrm{mol}$ [Farver and Yund, 2000] and $\sim 46 \mathrm{~kJ} / \mathrm{mol}$ [Tullis and Yund, 1982]), and accordingly, transport controlled GBM rates would vary as a function of temperature and the water-dependent migration mechanisms. However, this calls for a much better understanding of creep processes in nature; as for example, it is unclear which process constitutes the rate liming step during dislocation creep with GBM recrystallization, and so far, any prediction will be based on speculations.

\section{Summary and Conclusions}

Quartz grains of the Truzzo meta-granite mylonite (TGM) deformed by dislocation creep at amphibolite facies conditions have very low intragranular water contents (usually $<100 \mathrm{H} / 10^{6} \mathrm{Si}$ ). Grain boundary migration recrystallization dominates the microstructure and further reduced intragranular, molecular water contents, while it did not affect intracrystalline water. At the same time, intergranular water was present during mylonitization, with fluids expelled from inclusions into grain boundaries during recrystallization. The microstructure indicates that deformation must have taken place at relatively low differential stresses. Accumulated strain and the lack of high-stress microstructures indicate that the removal of intragranular water did not lead to any obvious hardening.

For this study, the method for deriving water contents from FTIR spectra was refined, and obtained values are compared to published data. Clear, magmatic, and especially recrystallized grains exhibit absorption spectra 
comparable to Brazil quartz. The water contents in the TGM and deformation microstructures indicate that dislocation creep at amphibolite facies conditions and natural strain rates does not require intragranular water contents as large as those needed in deformation experiments. In nature, quartz mylonites can deform by dislocation creep with GBM recrystallization when intragranular water contents are so low that their detection is difficult using current FTIR methods. Measuring low intragranular water content in naturally deformed rocks does not necessarily indicate a high strength of the material.

Application of experimentally determined flow laws to natural deformation will necessarily involve extrapolations in temperature, strain rate, and water-dependent processes in an independent manner. To explain why dry quartz can be weak in nature but not in deformation experiments, the rate limiting processes of dislocation creep need to be understood as a function of temperature and water content. Highest-temperature deformation experiments need to be refined in order to achieve a similar predictive quality as is assumed for the currently known experimental deformation regimes.

\section{Acknowledgments}

The visit of R.K. at Texas A\&M University, Center of Tectonophysics, was supported by the Swiss National Science Foundation grants NF200020-108082 and NF200020-119878. Marco Herwegh is kindly thanked for providing access to the EBSD facility at the University of Bern. SEM images were taken at the Center of Microscopy, University Basel. Willy Tschudin is thanked for excellent sample preparation. Raw spectra and samples can be acquired at the corresponding author. The two anonymous reviewers are kindly thanked for their constructive comments.

\section{References}

Aines, R., and G. Rossman (1984), Water in minerals - A peak in the infrared, J. Geophys. Res., 89(NB6), 4059-4071, doi:10.1029/ JB089iB06p04059.

Bakker, R. J., and J. B. H. Jansen (1994), A mechanism for preferential $\mathrm{H}_{2} \mathrm{O}$ leakage from fluid inclusions in quartz, based on TEM observations, Contrib. Mineral. Petrol., 116(1-2), 7-20, doi:10.1007/BF00310686.

Baudin, T., and D. Marquer (1993), Metamorphism and deformation in the Tambo Nappe (Swiss Central Alps) - Evolution of the phengite substitution during Alpine deformation, Schweiz. Mineral. Petrogr. Mitt., 73(2), 285-299.

Blacic, J. (1975), Plastic deformation mechanisms in quartz - Effect of water, Schweiz. Mineral. Petrogr. Mitt., 27(3), $271-294$.

Blacic, J. D., and J. M. Christie (1984), Plasticity and hydrolytic weakening of quartz single crystals, J. Geophys. Res., 89, 4223-4239.

Brunner, G., H. Wondratschek, and F. Laves (1961), Ultrarotuntersuchungen über den Einbau von H in natürlichem Quarz, Z. Elektrochem., 65(9), 735-750.

Chernak, L. J., G. Hirth, J. Selverstone, and J. Tullis (2009), Effect of aqueous and carbonic fluids on the dislocation creep strength of quartz, J. Geophys. Res., 114, B04201, doi:10.1029/2008JB005884.

Cordier, P., and J. Doukhan (1988), Water in quartz, point-defects, solubility, diffusivity and influence on ductility, Chem. Geol., 70(1-2), 158, doi:10.1016/0009-2541(88)90659-6.

Cordier, P., and J. Doukhan (1989), Water solubility in quartz and its influence on ductility, Eur. J. Mineral., 1(2), $221-237$.

Cordier, P., J. Weil, D. Howarth, and J. Doukhan (1994), Influence of the $(4 \mathrm{H})_{\mathrm{Si}}$ defect on dislocation-motion in crystalline quartz, Eur. J. Mineral., 6(1), 17-22.

den Brok, B., J. Meinecke, and K. Roller (1994), Fourier-transform IR-determination of intragranular water-content in quartzites experimentally deformed with and without added water in the ductile deformation field, J. Geophys. Res., 99(B10), 19,821-19,828, doi:10.1029/ 94JB01473.

den Brok, S. W. J., and C. J. Spiers (1991), Experimental evidence for water weakening of quartzite by microcracking and solution-precipitation creep, Geol. Soc. London J., 148, 541-548.

Derby, B., and M. Ashby (1987), On dynamic recrystallization, Scr. Metall., 21(6), 879-884, doi:10.1016/0036-9748(87)90341-3.

Doukhan, J., and M. Paterson (1986), Solubility of water in quartz - A revision, Bull. Mineral., 109(3), 193-198.

Drury, M. R., and J. L. Urai (1990), Deformation-related recrystallization processes, Tectonophysics, 172(3), $235-253$.

Farmer, V., and J. Russell (1964), The infra-red spectra of layer silicates, Spectrochim. Acta, 20(7), 1149-1173.

Farver, J., and R. Yund (2000), Silicon diffusion in a natural quartz aggregate: Constraints on solution-transfer diffusion creep, Tectonophysics, 325(3-4), 193-205.

Fitz Gerald, J., J. Boland, A. McLaren, A. Ord, and B. Hobbs (1991), Microstructures in water-weakened single-crystals of quartz, J. Geophys. Res., 96(B2), 2139-2155, doi:10.1029/90JB02190.

Fitz Gerald, J., N. Mancktelow, G. Pennacchioni, and K. Kunze (2006), Ultrafine-grained quartz mylonites from high-grade shear zones: Evidence for strong dry middle to lower crust, Geology, 34(5), 369-372, doi:10.1130/G22099.1.

Gerretsen, J., M. S. Paterson, and A. C. McLaren (1989), The uptake and solubility of water in quartz at elevated pressure and temperature, Phys. Chem. Miner., 16, 334-342, doi:10.1007/BF00199553.

Gleason, G. C., and S. DeSisto (2008), A natural example of crystal-plastic deformation enhancing the incorporation of water into quartz, Tectonophysics, 446(1-4), 16-30, doi:10.1016/j.tecto.2007.09.006.

Griggs, D. (1967), Hydrolytic weakening of quartz and other silicates, Geophys. J. R. Astron. Soc., 14(1-4), 19-31.

Griggs, D. (1974), Model of hydrolytic weakening in quartz, J. Geophys. Res., 79(11), 1653-1661, doi:10.1029/JB079i011p01653.

Griggs, D., and J. Blacic (1964), The strength of quartz in the ductile regime, Eos Trans. AGU, 45, 102-103.

Griggs, D., and J. Blacic (1965), Quartz: Anomalous weakness of synthetic crystals, Science, 147(3655), 292-295.

Heggie, M., and R. Jones (1986), Models of hydrolytic weakening in quartz, Philos. Mag. A, 53(5), L65-L70.

Heggie, M., R. Jones, C. Latham, S. Maynard, and P. Tole (1992), Molecular-diffusion of oxygen and water in crystalline and amorphous silica, Philos. Mag. B, 65(3), 463-471, doi:10.1080/13642819208207643.

Heilbronner, R., and S. Barrett (2014), Image Analysis in Earth Sciences, Springer-Verlag, Berlin Heidelberg.

Heilbronner, R., and C. Pauli (1993), Integrated spatial and orientation anlysis of quartz c-axes by computer-aided microscopy, J. Struct. Geol., 15, 369-382.

Hielscher, R., and H. Schaeben (2008), A novel pole figure inversion method: Specification of the MTEX algorithm, J. Appl. Crystallogr., 41, 1024-1037, doi:10.1107/S0021889808030112. [Available at https://mtex-toolbox.github.io/.]

Hirsch, P. (1981), Plastic deformation and electronic mechanisms in semiconductors and insulators, J. Phys. Colloq., 42, C3-149-C3-160. Hirth, G., and J. Tullis (1992), Dislocation creep regimes in quartz aggregates, J. Struct. Geol., 14(2), 145-159.

Hobbs, B. (1984), Point defect chemistry of minerals under a hydrothermal environment, J. Geophys. Res., 89, 4026-4038, doi:10.1029/ JB089iB06p04026. 
Hobbs, B. E. (1981), The influence of metamorphic environment upon the deformation of minerals, Tectonophysics, 78(1-4), 335-383, doi:10.1016/0040-1951(81)90020-2.

Holyoke, C. W., III, and A. K. Kronenberg (2013), Reversible water weakening of quartz, Earth Planet. Sci. Lett., 374, 185-190.

Huber, R., and D. Marquer (1998), The tectonometamorphic history of the peridotitic Chiavenna unit from Mesozoic to Tertiary tectonics: A restoration controlled by melt polarity indicators (Eastern Swiss Alps), Tectonophysics, 296(1-2), 205-223.

Ito, Y., and S. Nakashima (2002), Water distribution in low-grade siliceous metamorphic rocks by micro-FTIR and its relation to grain size: A case from the Kanto Mountain region, Japan, Chem. Geol., 189(1-2), 1-18, doi:10.1016/S0009-2541(02)00022-0.

Jaoul, O., J. Tullis, and A. Kronenberg (1984), The effect of varying water contents on the creep-behavior of Heavitree quartzite, J. Geophys. Res., 89(NB6), 4298-4312, doi:10.1029/JB089iB06p04298.

Kats, A. (1962), Hydrogen in alpha-quartz, Philips Res. Rep., 17(1-31), 133-279.

Kekulawala, K., M. Paterson, and J. Boland (1978), Hydrolytic weakening in quartz, Tectonophysics, 46(1-2), T1-T6.

Kilian, R., R. Heilbronner, and H. Stunitz (2011a), Quartz grain size reduction in a granitoid rock and the transition from dislocation to diffusion creep, J. Sruct.Geol., 33(8), 1265-1284, doi:10.1016/j.jsg.2011.05.004.

Kilian, R., R. Heilbronner, and H. Stunitz (2011b), Quartz microstructures and crystallographic preferred orientation: Which shear sense do they indicate?, J. Struct. Geol., 33(10), 1446-1466, doi:10.1016/j.jsg.2011.08.005.

Kirby, S. H., and J. W. McCormick (1979), Creep of hydrolytically weakened synthetic quartz crystals oriented to promote (2110) less-than0001-greater-than slip - brief summary of work to date, Bull. De Mineral., 102(2-3), 124-137.

Kronenberg, A. (1994), Hydrogen speciation and chemical weakening of quartz, Silica: Physical Behavior, Geochem. Mater. Appl. 29, 123-176.

Kronenberg, A., and J. Tullis (1984), Flow strengths of quartz aggregates - grain-size and pressure effects due to hydrolytic weakening, J. Geophys. Res., 89(NB6), 4281-4297, doi:10.1029/JB089iB06p04281.

Kronenberg, A., and G. Wolf (1990), Fourier transform infrared spectroscopy determinations of intragranular water content in quartz-bearing rocks: Implications for hydrolytic weakening in the laboratory and within the Earth, Tectonophysics, 172(3-4), $255-271$.

Kronenberg, A., S. Kirby, R. Aines, and G. Rossman (1986), Solubility and diffusional uptake of hydrogen in quartz at high water pressures: Implications for hydrolytic weakening, J. Geophys. Res., 91(B12), 2723-2744, doi:10.1029/JB091iB12p12723.

Kronenberg, A. K., P. Segall, and G. H. Wolf (1990), Hydrolytic weakening and penetrative deformation within a natural shear zone, in The Brittle-Ductile Transition in Rocks (The Heard Volume), Geophys. Monogr., vol. 56, edited by A. G. Duba et al., pp. 21-36, AGU, Washington, D. C.

Law, R. (1986), Relationships between strain and quartz crystallographic fabrics in the Roche Maurice quartzites of Plougastel, Western Brittany, J. Struct. Geol., 8(5), 493-515.

Libowitzky, E., and G. Rossman (1997), An IR absorption calibration for water in minerals, Am. Mineral., 82(11-12), 1111-1115.

Mainprice, D., and O. Jaoul (2009), A transmission electron microscopy study of experimentally deformed quartzite with different degrees of doping, Phys. Earth Planet. Inter., 172(1-2), 55-66, doi:10.1016/j.pepi.2008.07.009.

Mancktelow, N., and G. Pennacchioni (2004), The influence of grain boundary fluids on the microstructure of quartz-feldspar mylonites, J. Struct. Geol., 26(1), 47-69, doi:10.1016/S0191-8141(03)00081-6.

Mancktelow, N., and G. Pennacchioni (2010), Why calcite can be stronger than quartz, J. Geophys. Res., 115, B01402, doi:10.1029/2009JB006526.

Marquer, D. (1991), Structures and kinematic history of Alpine deformation in the Truzzo Granite (Tambo Nappe Central Alps, Switzerland), Eclogae Geol. Helv., 84(1), 107-123.

Marquer, D., T. Baudin, J. Peucat, and F. Peroz (1994), Rb-Sr mica ages in the Alpine shear zones of the Truzzo Granite: Timing of the Tertiary Alpine P-T deformations in the Tambo Nappe (Central Alps, Switzerland), Eclogae Geol. Helv., 87(1), 225-239.

McConnell, J. D. C. (1997), Ab initio studies on water related species in quartz and their role in weakening under stress, Phase Transitions, 61(1-4), 19-39, doi:10.1080/01411599708223727.

McLaren, A. C., R. F. Cook, S. T. Hyde, and R. C. Tobin (1983), The mechanisms of the formation and growth of water bubbles and associated dislocation loops in synthetic quartz, Phys. Chem. Miner., 9, 79-94, doi:10.1007/BF00308151.

McLaren, A. C., J. Fitz Gerald, and J. Gerretsen (1989), Dislocation nucleation and multiplication in synthetic quartz: Relevance to water weakening, Phys. Chem. Miner., 16(5), 465-482.

Menegon, L., P. Nasipuri, H. Stünitz, H. Behrens, and E. Ravna (2011), Dry and strong quartz during deformation of the lower crust in the presence of melt, J. Geophys. Res., 116, B10410, doi:10.1029/2011JB008371.

Nakashima, S., H. Matayoshi, T. Yuko, K. Michibayashi, T. Masuda, N. Kuroki, H. Yamagishi, Y. lito, and A. Nakamura (1995), Infrared microspectroscopy analysis of water distribution in deformed and metamorphosed rocks, Tectonophysics, 245(3-4), 263-276.

Niimi, N., N. Aikawa, and K. Shinoda (1999), The infrared absorption band at $3596 \mathrm{~cm}^{-1}$ of the recrystallized quartz from Mt. Takamiyama, southwest Japan, Mineral. Mag., 63(5), 693-701.

Pankrath, R. (1991), Polarized IR spectra of synthetic smoky quartz, Phys. Chem. Miner., 17(8), 681, doi:10.1007/BF00202238.

Pankrath, R., and O. Flörke (1994), Kinetics of Al-Si exchange in low and high quartz: Calculation of Al diffusion-coefficients, Eur. J. Mineral., 6(4), 435-457.

Panozzo, R. (1983), Two-dimensional analysis of shape-fabric using projections of digitized lines in a plane, Tectonophysics, 95, 279-294.

Panozzo, R. (1984), Two-dimensional strain from the orientation of lines in a plane, J. Struct. Geol., 6(1/2), $215-221$.

Passchier, C. (1985), Water-deficient mylonite zones-An example from the Pyrenees, Lithos, 18(2), 115-127, doi:10.1016/0024-4937(85)90014-3.

Paterson, M. (1982), The determination of hydroxyl by infrared-absorption in quartz, silicate-glasses and similar materials, Bull. Mineral., 105(1), 20-29.

Paterson, M. (1989), The interaction of water with quartz and its influence in dislocation flow-An overview, in Rheology of Solids and of the Earth, pp. 107-142, Oxford Sci. Publ., Oxford.

Paterson, M., and F. Luan (1990), Quartzite rheology under geological conditions, Geol. Soc. London, Spec. Publ., 54(1), $299-307$.

Paterson, M. S. (1986), The thermodynamics of water in quartz, Phys. Chem. Miner., 13, 245-255, doi:10.1007/BF00308276.

Paterson, M. S., B. E. Hobbs, and A. C. McLaren (1972), The plasticity of single crystals of synthetic quartz, Transactions of the American Geophysical Union (USA), American Geophysical Union 53rd Annual Meeting, vol. 53, pp. 514-15, AGU, Washington, D. C., 17-21 Apr.

Pennacchioni, G., and B. Cesare (1997), Ductile-brittle transition in pre-Alpine amphibolite facies mylonites during evolution from water-present to water-deficient conditions (Mont Mary Nappe, Italian Western Alps), J. Metamorph. Geol., 15(6), 777-791, doi:10.1111/ j.1525-1314.1997.00055.x.

Phillips, E. (1980), Myrmekite as a marker between pre-aqueous and post-aqueous phase saturation in granitic systems: Discussion, Geol. Soc. Am. Bull., 91(11), 672-673.

Post, A., and J. Tullis (1998), The rate of water penetration in experimentally deformed quartzite: Implications for hydrolytic weakening, Tectonophysics, 295(1-2), 117-137. 
Rovetta, M., J. Holloway, and J. Blacic (1986), Solubility of hydroxyl in natural quartz annealed in water at 900 degrees C and $1.5 \mathrm{GPa}$, Geophys. Res. Lett., 13(2), 145-148, doi:10.1029/GL013i002p00145.

Schmatz, J., and J. L. Urai (2011), The interaction of migrating grain boundaries and fluid inclusions in naturally deformed quartz: A case study of a folded and partly recrystallized quartz vein from the Hunsrück Slate, Germany, J. Struct. Geol., 33(4), 468-480.

Shimizu, I. (2008), Theories and applicability of grain size piezometers: The role of dynamic recrystallization mechanisms, J. Struct. Geol., 30(7), 899-917, doi:10.1016/j.jsg.2008.03.004.

Shinoda, K., and N. Aikawa (1993), Polarized infrared absorbance spectra of an optically anisotropic crystal: Application to the orientation of the $\mathrm{OH}$ - dipole in quartz, Phys. Chem. Miner., 20(5), 308-314, doi:10.1007/BF00215101.

Stipp, M., H. Stunitz, R. Heilbronner, and S. Schmid (2002), The eastern Tonale fault zone: A 'natural laboratory' for crystal plastic deformation of quartz over a temperature range from 250 to 700 degrees C, J. Struct. Geol., 24(12), 1861-1884.

Stipp, M., J. Tullis, and H. Behrens (2006), Effect of water on the dislocation creep microstructure and flow stress of quartz and implications for the recrystallized grain size piezometer, J. Geophys. Res., 111, B04201, doi:10.1029/2005JB003852.

Tarantola, A., L. Diamond, and H. Stünitz (2010), Modification of fluid inclusions in quartz by deviatoric stress I: Experimentally induced changes in inclusion shapes and microstructures, Contrib. Mineral. Petrol. 160(6), 825-843.

Thomas, S. M., M. Koch-Mueller, P. Reichart, D. Rhede, R. Thomas, R. Wirth, and S. Matsyuk (2009), IR calibrations for water determination in olivine, r-GeO2, and SiO2 polymorphs, Phys. Chem. Miner., 36(9), 489-509, doi:10.1007/s00269-009-0295-1.

Tullis, J., and R. A. Yund (1982), Grain growth kinetics of quartz and calcite aggregates, J. Geol., 90(3), 301-318.

Weathers, M., J. Bird, R. Cooper, and D. Kohlstedt (1979), Differential stress determined from deformation-induced microstructures of the Moine Thrust Zone, J. Geophys. Res., 84(NB13), 7495-7509, doi:10.1029/JB084iB13p07495.

Xia, Q.-K., X.-Z. Yang, E. Deloule, Y.-M. Sheng, and Y.-T. Hao (2006), Water in the lower crustal granulite xenoliths from Nushan, eastern China, J. Geophys. Res., 111(B11), doi:10.1029/2006JB004296.

Yund, R., B. Smith, and J. Tullis (1981), Dislocation-assisted diffusion of oxygen in albite, Phys. Chem. Miner., 7(4), 185-189, doi:10.1007/ BF00307264. 